\title{
Wind Loading on Solar Collectors
}

S. Bhaduri (University of Texas at El Paso) L. M. Murphy (Solar Energy Research Institute)

June 1985

Prepared under Task Nos. 1384.30 and 5102.31

FTP No. 463

Solar Energy Research Institute

A Division of Midwest Research Institute

1617 Cole Boulevard

Golden, Colorado 80401

Prepared for the

U.S. Department of Energy

Contract No. DE-AC02-83CH10093 



\section{PREFACE}

The research and development described in this document was conducted within the U.S. Department of Energy's Solar Thermal Technology Program. The goal of the Solar Thermal Technology Program is to advance the engineering and scientific understanding of solar thermal technology and to establish the technology base from which private industry can develop solar thermal power production options for introduction into the competitive energy market.

Solar thermal technology concentrates the solar flux by means of tracking mirrors or lenses onto a recelver where the solar energy "1s absorbed as heat and converted into electricity or incorporated into products as process heat. The two primary solar thermal technologies, central recelvers and distributed recelvers, employ various point and line-focus optics to concentrate sunlight. Current central recelver systems use flelds of hellostats (two-axis tracking mirrors) to focus the sun's radiant energy onto a single tower-mounted recelver. Parabolic dishes up to 17 meters in diameter track the sun in two axes and use mirrors or Fresnel lenses to focus radiant energy onto a recelver. Troughs and bowls are line-focus tracking reflectors that concentrate sunlight onto recelver tubes along their focal 1 ines. Concentrated collector modules can be used alone or in a multimodule system. The concentrated radiant energy absorbed by the solar thermal receiver is transported to the conversion process by a circulating working fluid. Recelver temperatures range from $100^{\circ} \mathrm{C}$ in $10 \mathrm{w}$-temperature troughs to over $1500^{\circ} \mathrm{C}$ in $\mathrm{dish}$ and central recelver systems.

The Solar Thermal Technology Program is directing efforts to advance and improve each system concept through the research and development of solar thermal materials, components, and subsystems, and the testing and performance evaluation of subsystems and systems. These efforts are carried out through the technical direction of DOE and its network of national laboratorles that work with private industry. Together they have established a comprehensive, goal-directed program to improve performance and provide technically proven options for eventual incorporation into the nation's energy supply.

To be successful in contributing to an adequate national energy supply at reasonable cost, solar thermal energy must eventually be economically competitive with a variety of other energy sources. Components and systemlevel performance targets have been developed as quantitative program goals. The performance targets are used in planning research and development activities, measuring progress, assessing alternative technology options, and making optimal component developments. These targets will be pursued vigorously to insure a successful program.

This specific report addresses wind loading on solar collectors since the determination of wind loading is one of the major design considerations in designing tracking and fleld-mounted solar collectors. The main objective of the report is to review and assess the present design methodology for wind loading on collectors for solar thermal applications and to recommend areas of further investigation for developing realistic criteria to determine reliable and adequate wind loads. The feasibility of using innovative design considerations to reduce the magnitude of wind loads on the solar collectors is also 
considered. This report contains valuable information regarding the comparative studies of various aspects of design methodology and should be of interest to design engineers and developers of solar collectors.

The authors would like to thank the numerous individuals at SERI who provided valuable discussions and support during the course of this study. In addition, the authors would like to thank those technologists outside of SERI who provided valuable comments and suggestions in their reviews of earlier drafts of this document; these are B111 Delemeter, Clayton Mavis, Jon Peterka, Jim Leonard, Martin Scheve, Frank Wilkins, Kenell Touryan, Jeff Shingleton, and Aharon Roy.

The first author extends his thanks and appreclation to the U.S. Department of Energy (DOE) and the American Society for Engineering Education (ASEE) for the opportunity to do this research at SERI. This area of research is supported by the DOE Solar Thermal Program under the direction of Frank Wilkins and Martin Scheve.

\section{Bhadurí}

S. Bhaduri

University of Texas at E1 Paso

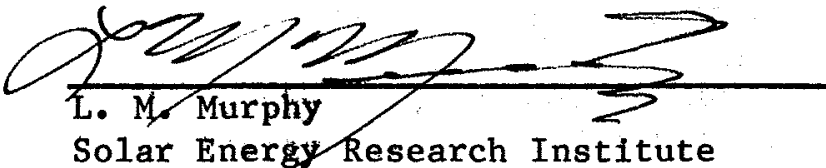

Approved for

SOLAR ENERGY RESEARCH INSTITUTE
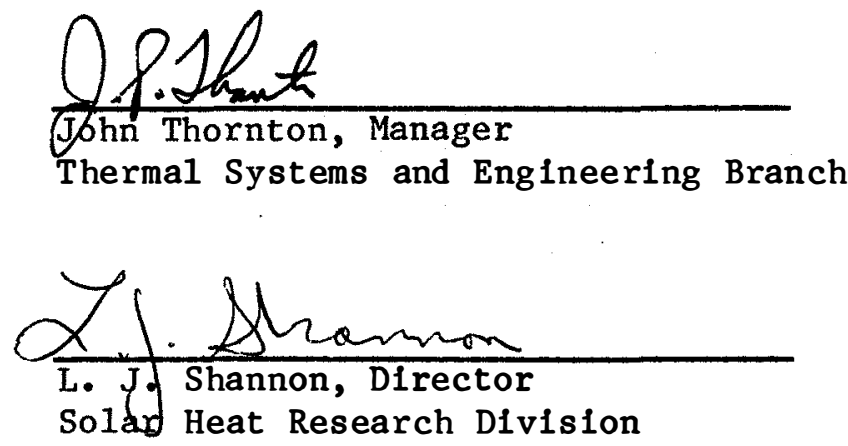


\section{SUMMARY}

\section{Objective}

The objective is to review and assess the present methodology for predicting and designing for wind loading on solar collectors for trough, dish, and hellostat applications and possibly for large fleld-mounted photovoltaic arrays. Another objective is to recommend areas of further investigation for developing realistic criteria to adequately determine the wind loads on these structures.

\section{Discussion}

The present method of determining the wind load, using the code ANSI A58.1-1982 of the American National Standard Institute, is overly conservative. The recent model studies of solar collectors in boundary layer wind tunnels under simulated atmospheric flow conditions yielded valuable information regarding the wind forces on the collectors and established varlous dimensionless force and moment coefficients corresponding to the mean wind velocities and their direction of approach. A significant amount of model testing was devoted to studies involving both individual collectors and flelds of collectors. The effects of porous fences or barriers at the edge of the collector field and the shielding effects of the adjacent collectors in the field in reducing the effective wind loads on the collectors were also studied in the wind tunnels at various test facilities. The results of these studies indicate that the wind load can be reduced considerably even beyond the levels that trough designers have already used.

\section{Conclusions and Recommendations}

In this study, the following were accomplished:

- Development of elevation-dependent longitudinal velocity profiles for various exposure conditions.

- Comparative study of the total force coefficient of a flat plate of various aspect ratios and at varlous angles of attack. Values obtained for the ANSI A58.1-1982 code, ASCE Task Comm. 1961 [23], and fu11-scale hellostat tests were used for the comparison.

- Comparative study of the spectra of longitudinal, vertical, and lateral velocity fluctuations. Spectra for the velocity fluctuations for frequency range 0.001-10.0 Hz were calculated and compared graphically. The spectra used for the Bullding Code ANSI A58.1-1982 and the spectra in Kalmal et al. [26] were considered.

- Estimation of the resultant angle of attack (relative to the horizonta1) of the turbulent wind fleld for varlous exposures such as open fleld and suburban location. This is particularly important when considering hellostats in the stowed position. The angle of attack due to turbulent fluctuating velocity is strongly dependent on the roughness parameter of the flow fleld. For a roughness element of $0.123 \mathrm{~m}(0.4 \mathrm{ft})$ in a 
suburban area, and wind speeds of $30 \mathrm{mph}, 50 \mathrm{mph}$, and $90 \mathrm{mph}$ at an elevation of $10 \mathrm{~m}(32.8 \mathrm{ft})$, the angles of attack due to fluctuating vertical velocity are $4.68^{\circ}, 4.60^{\circ}$, and $4.30^{\circ}$, respectively.

Recommendations for further studies that might reduce the wind loading on the collector are to

- Modify the flow locally by using a turbulence stimulator in the form of porous eaves around the hellostat to discourage the flow separation at the odges of the hellostat

- Determine experimentally the appropriate air gap between the modules to encourage ventilation around the module

- Study the effects of perimeter fences and fences in the field around a group of hellostat zones to reduce the overall wind load

- Determine the magnitude of wind speed and its direction by developing a wind rose for the hellostat fleld. A physical scale model of this heliostat fleld may be tested in the atmospheric wind tunnel to obtain information regarding the wind speed, its direction, and turbulent characteristics. 


\section{TABLE OF CONTENTS}

Page

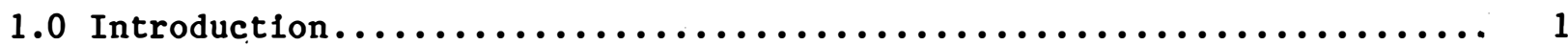

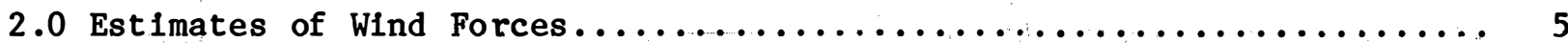

2.1 Atmospheric Turbulence Spectra....................... 19

2.2 Varlation of Wind Angle from the Horizontal............... 23

3.0 Reduction of $\mathrm{W}$.

4.0 Conclusion and Recommendations........................... 32

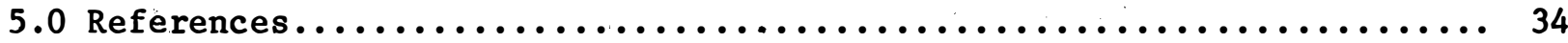




\section{LIST OF FIGURES}

$\underline{\text { Page }}$

2-1 Distribution of Gradient Wind for Various Exposures............. 9

2-2 Variation of Wind Speed with Elevation, $\left(U_{30}\right)_{C}=27$ mph.......... 14

2-3 Variation of Wind Speed with Elevation, $\left(\mathrm{U}_{30}\right)_{C}=50 \mathrm{mph} \ldots \ldots \ldots \ldots . . .14$

2-4 Variation of Wind Speed with Elevation, $\left(\mathrm{U}_{30}\right)_{C}=70 \mathrm{mph} \ldots \ldots \ldots \ldots . . .15$

2-5 Variation of Wind Speed with Elevation, $\left(U_{30}\right)_{C}=90$ mph......... 15

2-6 Variation of Velocity Pressure with wind Velocity............. 16

2-7 A Geometry for Flow past a Flat Plate................... 17

2-8 Varlation of Force Coefficlent with Angle of Attack, Aspect $\operatorname{Ratio}, \lambda=1.0 \ldots \ldots \ldots \ldots \ldots \ldots \ldots \ldots \ldots \ldots \ldots \ldots \ldots$

2-9 Varlation of Force Coefficlent with Angle of Attack, Aspect $\operatorname{Rat} 10, \lambda=3.0 \ldots \ldots \ldots \ldots \ldots \ldots \ldots \ldots \ldots \ldots \ldots \ldots \ldots \ldots . \ldots \ldots$

2-10 Longitudinal Turbulence Spectra, $U=44.73 \mathrm{mph} \ldots \ldots \ldots \ldots \ldots \ldots \ldots$

2-11 Turbulent Wind Spectra, $U=44.73 \mathrm{mph} \ldots \ldots \ldots \ldots \ldots \ldots \ldots \ldots \ldots \ldots \ldots$

2-12 Turbulent wind Spectra, $U=90.0 \mathrm{mph} \ldots \ldots \ldots \ldots \ldots \ldots \ldots \ldots \ldots$

2-13 Strong Wind Velocity Spectra of Daniels.................... 24

2-14 Peak Angle of Attack due to Turbulent Lateral Velocity........... 27

2-15 Peak Angle of Attack due to Turbulent Vertical Velocity.......... 28 


\section{LIST OF TABLES}

Page

$2-1$ Gradient Wind $\ldots \ldots \ldots \ldots \ldots \ldots \ldots \ldots \ldots \ldots \ldots \ldots \ldots \ldots \ldots \ldots \ldots \ldots$

2-2 Variation of Wind Velocity with Height, $\mathrm{U}_{30}=27.0 \mathrm{mph} \ldots \ldots \ldots$

2-3 Variation of Wind Velocity with Helght, $\mathrm{U}_{30}=50.0 \mathrm{mph} \ldots \ldots \ldots \ldots 11$

2-4 Variation of Wind Velocity with Helght, $U_{30}=70.0$ mph......... 12

2-5 Varlation of Wind Velocity with Helght, $U_{30}=90.0 \mathrm{mph} \ldots \ldots \ldots \ldots$

2-6 Veloc1ty Pressure............................... 16

2-7 Force Coefficient $C_{f}$ for Flow past a Flat Plate, Aspect Ratio,

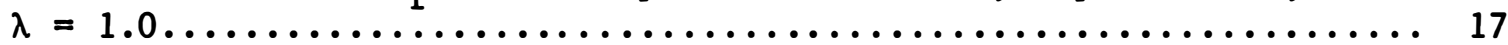

2-8 Force Coefficient $C_{f}$ for Flow past a Flat Plate, Aspect Ratio,

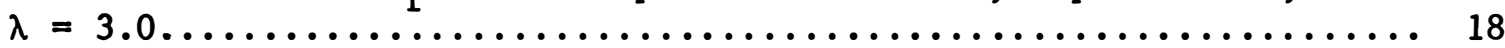

2-9 Dimensionless Constants for Longitudinal and Lateral Turbulence

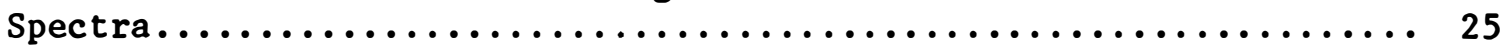

2-10 Variation of Angle of Attack due to Fluctuating Lateral Velocity.... 26

2-11 Varlation of Angle of Attack due to Fluctuating Vertical

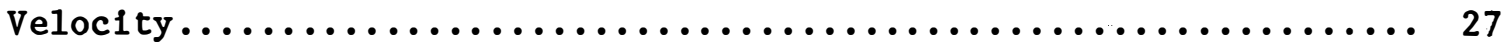




\section{NOMENCLATURE}

A,B,C,D basic exposure categories

A

characteristic surface area of collector, $\mathrm{m}^{2}\left(\mathrm{ft}^{2}\right)$

$\mathrm{C}_{\mathrm{f}}$

force coefficient, dimensionless

$\mathrm{C}_{\mathrm{M}}$

moment coefficient, dimensionless

F

wind force, $\mathrm{N}$ ( $1 \mathrm{bf}$ )

$F_{D}$

drag force, $N(1 b f)$

$\mathbf{F}_{\text {L }}$

lift force, $N(1 \mathrm{bf})$

f

Monin coordinate, dimensionless

$\mathrm{G}_{\mathbf{h}}$

gust response factor at helght $z=h$, dimensionless

$\mathrm{K}_{\mathrm{z}}$ velocity pressure exposure coefficlent at height $z$

L

moment arm.length, $m$ ( $f t$ )

M moment of a force, $N \mathrm{~m}$ (1bf $\mathrm{ft}$ )

n frequency, $\mathrm{Hz}$

dynamic pressure, $\mathrm{N} / \mathrm{m}^{2}\left(1 \mathrm{~b} / \mathrm{ft}^{2}\right)$

$\mathbf{q}_{\mathbf{z}}$

velocity pressure evaluated at helght $\mathrm{z}, \mathrm{N} / \mathrm{m}^{2}\left(1 \mathrm{~b} / \mathrm{ft}^{2}\right)$

$S(z, n)$

spectrum of longitudinal velocity fluctuations, $\mathrm{N} \mathrm{m} / \mathrm{n}$ (1bf $\mathrm{ft} s$ )

$S_{w}(z, n)$

spectrum of vertical velocity fluctuations, $\mathrm{N} \mathrm{m} / \mathrm{n}$ (1bf $\mathrm{ft} s$ )

$\mathrm{S}_{\mathrm{v}}(\mathrm{z}, \mathrm{n})$

spectrum of lateral velocity fluctuations, $\mathrm{N} / \mathrm{n}$ (1bf $\mathrm{ft} s$ )

$\mathrm{U}(\mathrm{z})$

mean velocity at height $z$

$\mathrm{U}_{\mathrm{g}}$

longitudinal component of velocity at gradient helght $\mathbf{z}_{\mathrm{g}}$

$\mathbf{U}_{\mathbf{z}}$

longitudinal component of velocity at helght $z$

$\mathrm{U}_{*}$

friction velocity, $\mathrm{m} / \mathrm{s}$ ( $\mathrm{ft} / \mathrm{s})$

V

basic wind velocity, $\mathrm{m} / \mathrm{s}$ (mph)

$\mathbf{z}$

vertical elevation, $m(f t)$

reference helght of ANSI code, $m(f t)$

${ }^{2} c$

$z_{g}$

$z_{r}$

$\alpha$

$\beta$

gradient helght, $m(f t)$

reference helght, $m$ ( $f t$ )

angle of attack, degree

$\lambda$ aspect ratio

coefficient $(z / z r)^{c 5}$

p

mass density, $\mathrm{kg} / \mathrm{m}^{3}\left(\mathrm{~s} 1 \mathrm{ug} / \mathrm{ft}^{3}\right)$

$\psi \quad$ stability parameter

$\omega$

frequency, $\mathrm{H}_{z}$ 


\section{SECTION 1.0}

\section{INTRODUCTION}

During the last two decades, there have been a number of significant developments in the meteorological aspects of the wind-loading problem. Advances in structural designs, particularly for high-rise structures, required accurate and more reliable meteorological information about the wind-loading processes. Varlous research results and historles of fallures of structures [1] indicate the damaging effects of repeated wind-induced loads on structures. Efforts have been made to design structures that resist the repeated loading action of wind $[2,3]$. This contradicts the more conventional design approach, which is mainly concerned with static application of a single large load derived from the guidelines furnished by the National Building Codes. Experience suggests that unserviceabllity due to repeated loading effects is a more likely occurrence than unserviceablilty or collapse from a single application of an exceptionally large load [4]. The common types of structural unserviceability caused by repeated wind loading are (1) fatigue failure, (2) foundation settlement, (3) excessive deflection, and (4) induced motion of unacceptable level. Fatigue fallure is an important design consideration even for the design of low-rise structures. Examples of fatigue fallure due to wind are found in structures such as towers, lamp standards, chimney stacks, and even bridges [5]. As innovative concentrator designs become less robust to reduce the amount of materials and costs required, all of these issues become more of a concern. An example of such a lightweight concentrator is the stretched-membrane heliostat.

Wind is one of the principal loads acting on above-ground engineering structures. An accurate determination of wind loading is a fundamental design consideration in deciding what degree of safety and economy can be achieved in such a structure. It is common practice to design structures to resist the highest wind to which they may be subjected. The highest wind is determined from the analysis of extreme value statistics of recorded wind velocities for a long period of time for a particular region.

The wind loads are considered in terms of a steady applied force, independent of the structure's shape, size, and dynamic characteristics, and a coefficient denoting the amplification that can arise through the interaction of the superimposed pressure fluctuations and the structure's dynamic response. The reliable estimate of this coefficient is quite involved and requires detailed knowledge of the site-specific wind climatology. The wind speeds used in current design specification are based on the U.S. Weather Bureau observation of the "fastest mile"* of wind (from distribution of extreme wind in the United States) multiplied by a gust factor to allow for the fluctuations in the wind speed. The gust response factor is a measure of the effective dynamic load produced by the gusts and is intended to translate the dynamic responses produced by the gust loading into simpler static design criterla. Although this

*"Fastest mile" corresponds to the highest (extreme) wind speed in miles per hour, measured at a standard helght of $33 \mathrm{ft}$ above the ground level in an open-country location. 
approach has often resulted in a safe, conservative estimate of wind loading, the neglect of the dynamic properties and size of the structure, the surface roughness, local obstructions, and the wind directions and their frequencles inherent in applying the fastest mile of wind could result in unsafe structures or in costly overdesigns.

Vellozzi and Cohen [6] leveloped a design methodology based on a power spectrum analysis of the dynamic structural response of a simple linear single degree of freedom system with viscous damping and reported measurements of wind gust spectra and gust correlation coefficients. The results of the analysis are presented in equations and charts that permit us to determine the gust response factors for bulldings and conventional structures. However, for structures like solar collectors, the method is not satisfactory since it does not account for the effects of surface roughness, terrain characteristics, and directional distribution of wind. We st111 do not understand the mechanism whereby gust pressure is induced on ground-based structures. Moreover, these design guidelines are applicable only to the situations where the principal wind loading is drag. Lateral and vertical wind components normal to the gross flow direction and gustiness are not considered.

Davenport [7] used a statistical approach to estimate the mean gradient wind speed that has a specifled return period or probability of exceeding on the basis of the mode and dispersion factor for the extreme gradient wind speed fleld at the site of the structure. This method may be used to determine the mean wind speed at some specific height above the ground if a rellable estimate of ground roughness and exposure of the site is avallable. The ground roughness is the princlpal parameter governing the mean wind speed profile and gustiness. Knowing the mean wind speed at the structure height corresponding to the gradient speed and the ground roughness, we can define the vertical and horizontal gust spectra. Davenport based his estimate of the gust force superimposed on the mean wind forces on the lateral gust spectra.

In his ploneering paper, Davenport [7] outlined the rationale for determining the design wind velocities. Briefly, he considered the extreme value statistics of the site, specific wind velocity, local ground roughness and exposure characteristics, wind direction rosettes, and a weighting parameter. The methodology outlines the determination of the basic design wind velocity that corresponds to the extreme sustained wind velocity giving rise to the steady component of the pressure. This velocity is essentially an average velocity, and the determination of a suitable averaging interval is an important feature of the method. Davenport attempts to process the records from a wide variety of anemometers of differing exposures and periods of records and to determine statistically how the records may be related to one another. This minimizes the systematic errors that may arise in the records because of uncontrolled anemometer siting and improves the records' overall reliability. The influence of the local surface roughness on both the magnitude of surface velocities and the increase of velocity with height is very important. Combining these results with extreme value statistics [8] leads to a qualitative method through which basic design wind velocities of a given probability of occurrence may be predicted for locations of differing surface roughness. 
Thom [9] introduced the concept of the annual fastest mile wind speed as the best available measure of wind speed for design purposes. The physical model for the boundary shear layer was assumed to have a standard level of $9.14 \mathrm{~m}$ (30 ft) and a velocity profile using a $1 / 7$ power law. Computational methods were developed for fitting the Fisher-Tippett Type II extreme value distribution [10], which fitted the data we11. The methods developed [9] were applied to the airport and open-country data series for 138 stations; maps were drawn for the 2-year, 50-year, and 100-year mean recurrence intervals. These maps received general acceptance as the U.S. standards. The methods of determining other quantities, such as probabilities for a fixed period and confidence limits for the estimates obtained from the maps, were given.

In his subsequent paper, Thom [11] observed that the distribution of the logarithm of a Fisher-Tippett Type II (Frechet) distribution [5] is a logarithmic transformation of the Type I distribution. Although this fact was not used in the previous paper, further examination of the extensive nonextreme wind data showed that such data follow a log normal distribution closely, which would indicate a Type I distribution for the extreme of the logarithm. This also substantiates the validity of the choice of the Frechet distribution for extreme winds. The maps developed by Thom [11] in which the Type I distribution is fit by order statistics to 150 stations were used extensively as the ANSI standard for building codes of the United States. The maps depicted the isotech lines in miles per hour of the annual extreme mile,

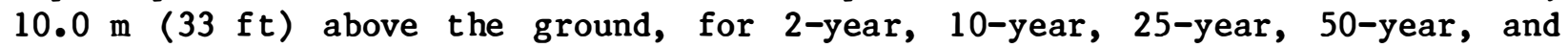
100-year mean recurrence intervals.

The basic wind speeds used to determine the design wind loads on buildings and other structures are given in Figure 1 of the ANSI A58.1-1982 code [12] for the contiguous United States and Alaska and in Table 7 for Hawail and Puerto Rico. Special considerations are allowed for those regions for which records or experience indicate that the wind speeds are lighter than those indicated in Figure 1 and Table 7 of the code [12]. The ANSI A58.1-1982 code also allows estimation of the basic wind speed based on regional climatic data and extreme value statistical analysis; however, the basic wind speed must be at least $70 \mathrm{mph}$.

All investigators recognize the qualitative nature of the idealized isotech lines based on data collected under diverse conditions and suggest that they be used with great care in determining the wind load for a specific structure in a specific site. Often, the probability of exceeding a particular wind velocity for a certain recurrence interval is related to the degree of risk associated with the lifetime of the structure. The probability that a structure will be subjected to a magnitude of wind loading is not site specific since wind data do not reflect the true nature of wind distribution at the site in question. The ground roughness, the exposure features, wind direction, and terrain conditions are not included in the methodology used by the codes.

The American National Standard A58.1-1982 [12] contains a definition of design wind speed in terms of the mean recurrence interval or return period. For a mean recurrence interval, the corresponding design wind speed is calculated from the expression of the cumulative distribution function of the extreme wind. The parameters of this function are estimated from the data of the 
largest wind speed for every year on record. The mean recurrence interval to be used in the design is selected as a function of "intended operational usage, anticipated life of the structure, degree of sensitivity to wind and the risk of loss of human life and property in case of failure" [12]. Implicit in the selection of the mean recurrence interval is the assumption that a given recurrence interval will ensure the same level of safety for any two structures subjected to wind loads provided that the reliability of the two structures is equal. Simiu [13] examined the validity of this simplified assumption and showed conclusively that the use of design wind maps based on the standard mean recurrence interval does not ensure a consistent level of safety for structures subjected to wind loads. Simiu emphasized that extensive research is required to develop regional and site-specific wind speed provisions based on a reliability consideration.

Because of the uncertainty and qualitative nature of the methodology used to estimate wind loading on structures, it seems reasonable to obtain the design parameters from simulation studies of sites under various wind speeds and wind directions. Various simulated experimental studies in the wind tunnels have already yielded valuable information.

Murphy [14] reviewed the existing methodologies for estimating the wind loading on solar collectors. He summarized 33 studies relevant to wind loading on solar collectors, heliostats, and photovoltaic arrays. The report, which contains valuable information regarding the present state of the art, has been used as a guide for this study.

Roschke [15] examined the problems and complications arising from wind loading on solar concentrators. He emphasized the site-specific nature of wind loading with associated important bearing on the design, cost, performance, operation and maintenance, safety, survival, and replacement of solar collectors, particularly the paraboloidal concentrators.

The primary objective of this study is to review and assess the present design methodology on wind loading on solar collectors, particularly the heliostats, and to recommend areas of further investigation to define realistic criteria for determining adequate wind loads. The model testing of the solar collectors in the environmental wind tunnels [16,17] indicates that it is possible to reduce the wind load considerably. In view of the feasibility of load reduction, we compare studies of the total force coefficient of a flat plate of various aspect ratios and at various angles of attack and studies of the spectra of longitudinal, vertical, and lateral velocity fluctuations. The angles of attack of the turbulent wind to the horizontally placed flat plate are important because of their effects on the net moment of the structure. We attempt to estimate the magnitude of angles from turbulent spectrum analysis.

This study does not consider the wind-loading effects caused by turbulence; i.e., (1) buffeting, (2) vortex shedding forces produced by the structure's own wake acting on the afterbody of the structure behind the separation point, and (3) aeroelastic forces induced by the oscillating motion of the structure. 
SECTION 2.0

ESTIMATES OF UIND FORCES

The wind load on the low-height structures, such as hellostats extending over a large land area, is a major design consideration. Properly determining the wind loads on the heliostats is essentlal for realistic structural designs and cost estimates. The ANSI A58.1-1982 code [12] is commonly used as a design guide. The code is primarily developed for bulldings and other structures. Generally, estimates are made, in the absence of more rellable experimental values obtained from model study, by considering the hellostats as other structures.

The wind force $F$ on a structure is given by

$$
F=q_{z} G_{h} C_{f} A_{p}
$$

where

$$
\begin{aligned}
& \mathrm{q}_{\mathrm{z}}=\text { velocity pressure evaluated at height } \mathrm{z} \text { above ground }\left(1 \mathrm{~b} / \mathrm{ft}^{2}\right) * \\
& \mathrm{G}_{\mathrm{h}}=\text { gust response factor at height } \mathrm{z}=\mathrm{h} \\
& \mathrm{C}_{\mathrm{f}}=\text { force coefficient } \\
& \mathrm{A}_{\mathrm{p}}=\text { projected area normal to wind. }
\end{aligned}
$$

The velocity pressure $q_{z}$ is calculated from the standard formula [12]

$$
q_{z}=0.00256 K_{z} v^{2} \text {, }
$$

where

$$
\begin{aligned}
& \mathrm{K}_{\mathrm{z}}=\text { velocity pressure exposure coefficient at height } \mathrm{z} \\
& \mathrm{V}=\text { basic } \text { wind speed }(\mathrm{mph}) .
\end{aligned}
$$

The values of the various coefficlents and factors are taken from the tables provided in the code for various exposures of the site of the structure. An exposure category is determined for the site at which the structure is situated. It reflects the characteristics of ground surface irregularities. Generally, four basic exposure categories are considered. Exposures A, B, C, and $D$ represent the large city center, urban and suburban areas, open terrain, and flat, unobstructed coastal areas, respectively.

* Since the standards and codes used for comparative assessments are described in their original form using English units, SI units will follow the English equivalents. 
The structure is designed for the environmental conditions with specified wind speed and mean recurrence interval. Generally, operating environmental conditions and extreme environmental conditions with assumed mean recurrence interval and expected life of the structure are considered to estimate the probability of exceeding the maximum design wind velocity. The probability is derived from the consideration of the extreme value ordered statistics of Thom [9]. The probability of exceeding the design velocity, or risk of occurrence as it is called, is not based on site-specific extreme wind records. The recorded wind data at the airport of a relatively large city may not be applicable to a smaller suburban city 50 miles away with different terrain features. In fact Simiu [13], Davenport [7], and McDonald [18] have questioned the validity of the basic assumptions and simplified methodology.

The variation of longitudinal component of wind velocity with elevation in the earth's lower atmosphere is expressed by

where

$$
\mathrm{U}_{\mathrm{z}}=\mathrm{U}_{\mathrm{g}}\left(\frac{\mathrm{z}}{\mathrm{z}_{\mathrm{g}}}\right)^{\mathrm{n}},
$$

$$
\begin{aligned}
& \mathrm{U}_{\mathrm{z}}=\text { longitudinal component of velocity at height } \mathrm{z} \\
& \mathrm{U}_{\mathrm{g}}=\text { longitudinal component of velocity at gradient height } \mathbf{z}_{\mathrm{g}} \\
& \mathrm{n}=\text { an exponent. }
\end{aligned}
$$

The following analytical relations of the velocity profiles relative to the velocity $\mathrm{U}_{30}$ at a helght equal to $30 \mathrm{ft}$ have been derived for ready reference.

$$
\begin{aligned}
\text { Exposure } C: \quad z_{g} & =900.0 \mathrm{ft} \quad \mathrm{n}=0.1429 \\
U_{z} & =U_{30}\left(\frac{z}{30}\right)^{0.1429}
\end{aligned}
$$

Exposure B: $z_{g}=1200.0 \mathrm{ft} \quad \mathrm{n}=0.2222$

$$
\mathrm{U}_{\mathrm{z}}=\mathrm{U}_{30}\left(\frac{\mathrm{z}}{30}\right)^{0.2222}
$$

$$
\text { Exposure A: } \begin{aligned}
\mathrm{z}_{\mathrm{g}} & =1500.0 \mathrm{ft} \quad \mathrm{n}=0.3333 \\
\mathrm{U}_{\mathrm{z}} & =\mathrm{U}_{30}\left(\frac{\mathrm{z}}{30}\right)^{0.3333} .
\end{aligned}
$$

The longitudinal components of wind velocity at elevation $z=30 \mathrm{ft}$ for the exposure conditions $A, B$, and $C$ are related by

and

$$
\left(\mathrm{U}_{30}\right)_{\mathrm{B}}=0.7163\left(\mathrm{U}_{30}\right)_{\mathrm{C}}
$$

$$
\left(\mathrm{U}_{30}\right)_{\mathrm{A}}=0.4414\left(\mathrm{U}_{30}\right)_{\mathrm{C}} \text {. }
$$


Table 2-1 shows the distribution of gradient wind for various exposures. Figure 2-1 graphically shows the dimensionless gradient wind distribution with elevation for the exposures of $A, B$, and $C$. Tables 2-2 through 2-5 give the values of the velocity variation with height for reference velocities of $27.0 \mathrm{mph}, 50.0 \mathrm{mph}, 70.0 \mathrm{mph}$, and $90.0 \mathrm{mph}$, respectively. Figures 2-2 through 2-5 show the variations of wind speed with elevation for the exposures. $\left(\mathrm{U}_{30}\right)_{C}$ is the velocity of wind at an elevation $z=30 \mathrm{ft}$ for exposure category C. Table 2-6 gives the computed values of velocity pressure obtained from the formula $\mathrm{q}_{\mathrm{z}}=0.00256 \mathrm{v}^{2}$. Figure 2-6 shows the variation of velocity pressure with wind velocity.

In recent years, the model studies of structures in simulated flow flelds have ylelded more rellable wind-load design values expressed in terms of dimensionless force and moment coefficients. The aerodynamics of structures in turbulent shear flows of the earth's lower atmosphere involve nonlinear interaction of the turbulent approach--flow with highly complex turbulent boundary layers and subsequent boundary layer separation and turbulent wake formation. Cermak [19] and Bhaduri [20] showed the feasibility of simulating the earth's boundary layers in the properly designed wind tunnel. Lindsay [21], Randall et al. [22], Peglow [16], and Xerikos et al. [17] tested the models of the solar collectors, hellostats, and hellostat arrays in the environmental wind tunnels and presented useful experimental results that could be used for determining design wind loads.

Based on the principle of similitude in model studies, the equality of the force and moment coefficients for the model and for the prototype, respectively, is well established. The force coefficient $\mathrm{C}_{\mathrm{f}}$ is defined by

$$
c_{\mathrm{f}}=\frac{\mathrm{F}}{\mathrm{qA}_{\mathrm{p}}}
$$

where

$$
\begin{aligned}
& F=\text { resultant force acting on the structure } \\
& q=\text { dynamic pressure, often called velocity pressure } \\
& A_{p}=\text { projected area normal to wind. }
\end{aligned}
$$

The moment coefficient $C_{M}$ is defined by

$$
C_{M}=\frac{M}{q_{p} L} \text {, }
$$

where

$$
\begin{aligned}
& \mathrm{M}=\text { moment of the total force about a reference point } \\
& \mathrm{L}=\mathrm{a} \text { characteristic moment arm length. }
\end{aligned}
$$

The dynamic pressure $q$ is expressed by

$$
\mathrm{q}=\frac{1}{2} \mathrm{pU}^{2},
$$


Table 2-1. Gradient Wind

\begin{tabular}{|c|c|c|c|c|c|c|}
\hline \multirow{3}{*}{$z(f t)$} & \multicolumn{2}{|c|}{$C$} & \multicolumn{2}{|r|}{ B } & \multicolumn{2}{|r|}{ A } \\
\hline & $z_{g}=$ & $\begin{array}{l}00 \mathrm{ft} \\
74.32 \mathrm{~m})\end{array}$ & $z_{g}=$ & $\begin{array}{l}1200 \mathrm{ft} \\
(365.76 \mathrm{~m})\end{array}$ & $\mathrm{z}_{\mathrm{g}}=$ & $\begin{array}{l}1500 \mathrm{ft} \\
(457.20 \mathrm{~m})\end{array}$ \\
\hline & $z / z_{g}$ & $\mathrm{U} / \mathrm{U}_{\mathrm{g}}$ & $z / z_{g}$ & $\mathrm{U} / \mathrm{U}_{\mathrm{g}}$ & $z / z_{g}$ & $\mathrm{U} / \mathrm{U}_{\mathrm{g}}$ \\
\hline 0 & 0 & 0 & 0 & 0 & 0 & 0 \\
\hline 15 & 0.017 & 0.557 & 0.013 & 0.378 & 0.010 & 0.215 \\
\hline 30 & 0.033 & 0.615 & 0.025 & 0.441 & 0.020 & 0.271 \\
\hline 40 & 0.044 & 0.641 & 0.033 & 0.470 & 0.027 & 0.299 \\
\hline 50 & 0.056 & 0.662 & 0.042 & 0.494 & 0.033 & 0.322 \\
\hline 75 & 0.083 & 0.701 & 0.063 & 0.540 & 0.050 & 0.368 \\
\hline 100 & 0.111 & 0.731 & 0.083 & 0.576 & 0.067 & 0.406 \\
\hline 200 & 0.222 & 0.807 & 0.167 & 0.672 & 0.133 & 0.511 \\
\hline 300 & 0.333 & 0.855 & 0.250 & 0.735 & 0.200 & 0.585 \\
\hline 400 & 0.444 & 0.891 & 0.333 & 0.783 & 0.267 & 0.644 \\
\hline 500 & 0.555 & 0.919 & 0.417 & 0.823 & 0.333 & 0.693 \\
\hline 600 & 0.667 & 0.944 & 0.500 & 0.857 & 0.400 & 0.737 \\
\hline 700 & 0.778 & 0.965 & 0.583 & 0.887 & 0.467 & 0.776 \\
\hline 800 & 0.889 & 0.983 & 0.667 & 0.914 & 0.533 & 0.811 \\
\hline 900 & 1.000 & 1.000 & 0.750 & 0.938 & 0.600 & 0.843 \\
\hline 1000 & & & 0.833 & 0.960 & 0.667 & 0.874 \\
\hline 1100 & & & 0.917 & 0.981 & 0.733 & 0.902 \\
\hline 1200 & & & 1.000 & 1.000 & 0.800 & 0.928 \\
\hline 1300 & & & & & 0.867 & 0.953 \\
\hline 1400 & & & & & 0.933 & 0.977 \\
\hline 1500 & & & & & 1.000 & 1.000 \\
\hline
\end{tabular}




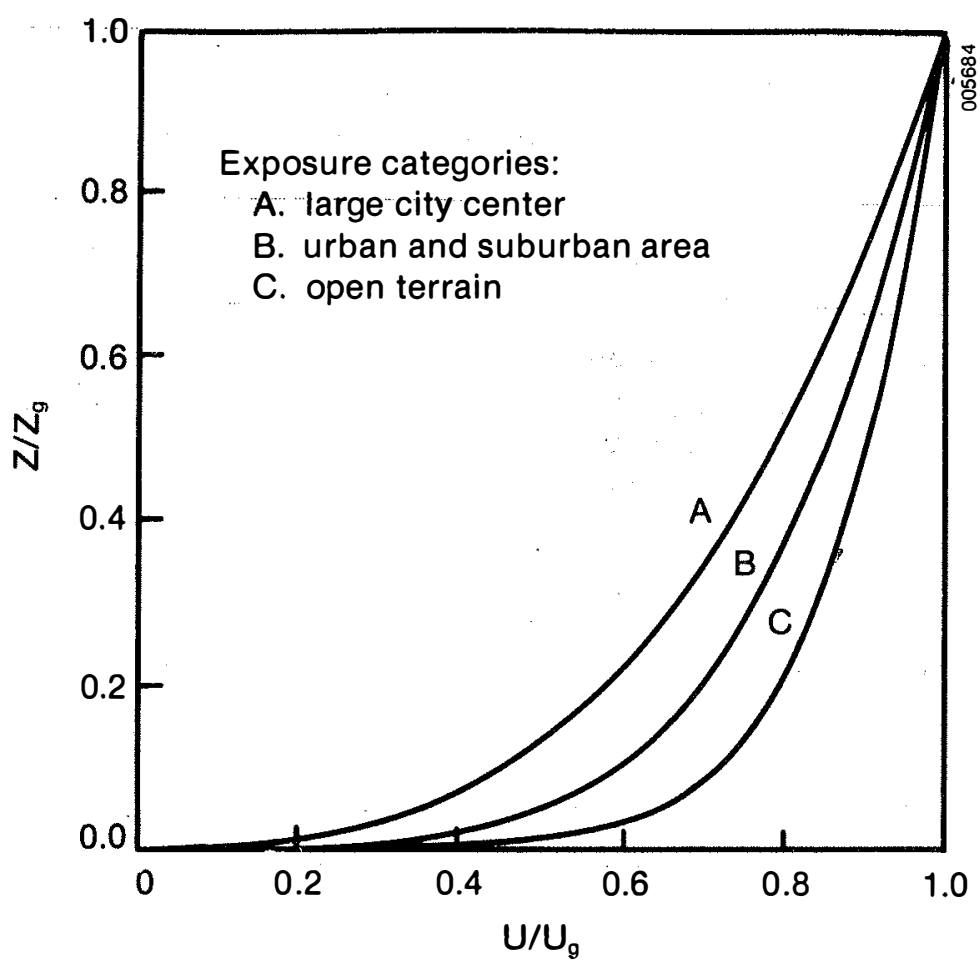

Figure 2-1. Distribution of Gradient Wind for Various Exposures

where

$$
\begin{aligned}
& \rho=\text { mass density of air } \\
& \mathrm{U}=\text { mean approach velocity. }
\end{aligned}
$$
The wind effects can be resolved into two force components--drag force $F_{D}$ and
lift force $F_{L}$. They are expressed as

$$
F_{D}=C_{D} q A_{p}
$$

where

$$
\begin{aligned}
& C_{D}=\text { drag coefficient } \\
& A_{p}=\text { projected area normal to the wind; }
\end{aligned}
$$

and

$$
\mathrm{F}_{\mathrm{L}}=\underset{\mathrm{L}}{\mathrm{CA}_{\mathrm{p}}}
$$

where

$$
C_{L}=11 f t \text { coefficient }
$$

From the vector nature of the force and its components, it can be shown that

$$
F=\left(F_{D}^{2}+F_{L}^{2}\right)^{1 / 2} \text {, }
$$


Table 2-2. Varfation of Wind Velocity with Beight, $\mathrm{U}_{30}=27 \mathrm{mph}(12 \mathrm{~m} / \mathrm{s})$

\begin{tabular}{|c|c|c|c|c|c|c|}
\hline \multirow{2}{*}{$\begin{array}{l}\text { Elevation } \\
\quad(\mathrm{ft})^{\mathrm{a}}\end{array}$} & \multicolumn{2}{|c|}{ Exposure $C$} & \multicolumn{2}{|c|}{ Exposure B } & \multicolumn{2}{|c|}{ Exposure A } \\
\hline & $\begin{array}{c}\text { Wind Speed } \\
V \\
(\mathrm{mph})^{\mathrm{b}}\end{array}$ & $\begin{array}{c}\text { Velocity } \\
\text { Pressure } \\
\mathrm{q}\left(1 \mathrm{~b} / \mathrm{ft}^{2}\right)^{\mathrm{c}}\end{array}$ & $\begin{array}{c}\text { Wind Speed } \\
\mathrm{V} \\
(\mathrm{mph})\end{array}$ & $\begin{array}{l}\text { Velocity } \\
\text { Pressure } \\
\mathrm{q}\left(1 \mathrm{~b} / \mathrm{ft}^{2}\right)\end{array}$ & $\begin{array}{c}\text { Wind Speed } \\
\mathrm{V} \\
(\mathrm{mph})\end{array}$ & $\begin{array}{l}\text { Velocity } \\
\text { Pressure } \\
\mathrm{q}\left(1 \mathrm{~b} / \mathrm{ft}^{2}\right)\end{array}$ \\
\hline 0 & 0 & 0 & 0 & 0 , & 0 & 0 \\
\hline 10 & 23.1 & 1.37 & 15.2 & 0.59 & 8.3 & 0.18 \\
\hline 15 & 24.6 & 1.55 & 16.6 & 0.71 & 9.5 & 0.23 \\
\hline 20 & 25.6 & 1.68 & 17.7 & 0.80 & 10.4 & 0.28 \\
\hline 25 & 26.4 & 1.78 & 18.6 & 0.89 & 11.2 & 0.32 \\
\hline 30 & 27.0 & 1.87 & 19.4 & 0.96 & 12.0 & 0.37 \\
\hline 40 & 28.20 & 2.04 & 20.7 & 1.10 & 13.2 & 0.45 \\
\hline 50 & 29.2 & 2.18 & 21.7 & 1.21 & 14.2 & 0.52 \\
\hline 75 & 30.86 & 2.44 & 23.8 & 1.46 & 16.2 & 0.67 \\
\hline 100 & 32.2 & 2.65 & 25.3 & 1.64 & 17.9 & 0.82 \\
\hline 150 & 34.1 & 2.98 & 27.7 & 1.96 & 20.4 & 1.07 \\
\hline 200 & 35.4 & 3.21 & 29.6 & 2.24 & 22.5 & 1.30 \\
\hline 300 & 37.6 & 3.62 & 32.3 & 2.67 & 25.7 & 1.69 \\
\hline 500 & 40.2 & 4.14 & 36.2 & 3.35 & 30.50 & 2.38 \\
\hline 700 & 42.4 & 4.60 & 39.0 & 3.89 & 34.1 & 2.98 \\
\hline 900 & 44.0 & 4.96 & 41.28 & 4.36 & 37.1 & 3.52 \\
\hline 1000 & & & 42.3 & 4.58 & 38.5 & 3.79 \\
\hline 1100 & & & 43.2 & 4.78 & 39.7 & 4.03 \\
\hline 1200 & & & 44.0 & 4.96 & 40.9 & 4.28 \\
\hline 1300 & & & & & 42.0 & 4.52 \\
\hline 1400 & & & & & 43.0 & 4.73 \\
\hline 1500 & & & & & 44.0 & 4.96 \\
\hline
\end{tabular}

$a_{\text {To }}$ convert to $\mathrm{m}$, multiply by 0.3048 .

$\mathrm{b}_{\text {To }}$ convert to $\mathrm{m} / \mathrm{s}$, multiply by 0.447 .

$\mathrm{c}_{\text {To }}$ convert to $\mathrm{Pa}$, multiply by 47.88 . 
Table 2-3. Variation of Wind Velocity with Beight, $\mathrm{U}_{30}=50 \mathrm{mph}(22 \mathrm{~m} / \mathrm{s})$

\begin{tabular}{|c|c|c|c|c|c|c|}
\hline \multirow{2}{*}{$\begin{array}{l}\text { Elevation } \\
\quad(f t)^{a}\end{array}$} & \multicolumn{2}{|c|}{ Exposure C } & \multicolumn{2}{|c|}{ Exposure B } & \multicolumn{2}{|c|}{ Exposure A } \\
\hline & $\begin{array}{c}\text { Wind Speed } \\
\mathrm{V} \\
(\mathrm{mph})^{\mathrm{b}}\end{array}$ & $\begin{array}{c}\text { Velocity } \\
\text { Pressure } \\
\left.\text { p (1b/ft }{ }^{2}\right)^{c}\end{array}$ & $\begin{array}{c}\text { Wind Speed } \\
\mathrm{V} \\
(\mathrm{mph})\end{array}$ & $\begin{array}{r}\text { Velocity } \\
\text { Pressure } \\
q\left(1 \mathrm{~b} / \mathrm{ft}^{2}\right)\end{array}$ & $\begin{array}{c}\text { Wind Speed } \\
\mathrm{V} \\
(\mathrm{mph})\end{array}$ & $\begin{array}{r}\text { Velocity } \\
\text { Pressure } \\
q\left(1 \mathrm{~b} / \mathrm{ft}^{2}\right)\end{array}$ \\
\hline 0 & 0 & 0 & 0 & 0 & 0 & 0 \\
\hline 10 & 42.8 & 4.69 & 28.1 & 2.02 & 15.3 & 0.60 \\
\hline 15 & 45.4 & 5.28 & 30.8 & 2.43 & 17.6 & 0.79 \\
\hline 20 & 47.3 & 5.73 & 32.8 & 2.75 & 19.3 & 0.95 \\
\hline 25 & 48.8 & 6.10 & 34.5 & 3.05 & 20.8 & 1.11 \\
\hline 30 & 50.0 & 6.40 & 35.9 & 3.30 & 22.1 & 1.25 \\
\hline 40 & 52.2 & 6.98 & 38.30 & 3.76 & 24.40 & 1.52 \\
\hline 50 & 53.9 & 7.44 & 40.2 & 4.14 & 26.2 & 1.76 \\
\hline 75 & 57.1 & 8.35 & 44.0 & 4.96 & 30.0 & 2.30 \\
\hline 100 & 59.5 & 9.06 & 46.9 & 5.63 & 33.1 & 2.80 \\
\hline 200 & 65.7 & 11.05 & 54.7 & 7.66 & 41.6 & 4.43 \\
\hline 500 & 74.9 & 14.36 & 67.1 & 11.53 & 56.5 & 8.17 \\
\hline 700 & 78.6 & 15.82 & 72.3 & 13.38 & 63.2 & 10.23 \\
\hline 900 & 81.5 & 17.00 & 76.5 & 14.90 & 68.7 & 12.08 \\
\hline 1200 & & & 81.5 & 17.00 & 75.7 & 14.67 \\
\hline 1500 & & & & & 81.5 & 17.00 \\
\hline
\end{tabular}

a To convert to $\mathrm{m}$, multiply by 0.3048 .

bo convert to $\mathrm{m} / \mathrm{s}$, multiply by 0.447 .

To convert to $\mathrm{Pa}$, multiply by 47.88 .

and

$$
C_{f}=\left(C_{D}^{2}+C_{L}^{2}\right)^{1 / 2}
$$

To compare the values of $C_{f}$ obtained by using the guidelines of the ANSI A58.1-1982 code with the values obtained by using the methodology of the ASCE Task Committee of 1961 [23], flows past vertical plates with aspect ratios, $\lambda=$ (width/helght), of 3 and 1 are considered (see Figure 2-7). The experimental results of Peglow's [16] full-scale test of a hellostat of aspect ratio $\lambda=1.0$ are also used for the comparison. For angles of attack of $0^{\circ}-30^{\circ}$, the corresponding values of force coefficient $C_{f}$ are taken from Table 11 of ANSI A58.1-1982 code [12] and Figure 5(d) of Paper 3269 of the 
Table 2-4. Variation of Wind Velocity with Height, $\mathrm{U}_{30}=70 \mathrm{mph}(31 \mathrm{~m} / \mathrm{s})$

\begin{tabular}{|c|c|c|c|c|c|c|}
\hline \multirow{2}{*}{$\begin{array}{l}\text { Elevation } \\
\left(f t^{2}\right)^{a}\end{array}$} & \multicolumn{2}{|c|}{ Exposure C } & \multicolumn{2}{|c|}{ Exposure B } & \multicolumn{2}{|c|}{ Exposure A } \\
\hline & $\begin{array}{l}\text { Wind Speed } \\
V_{(m p h)^{b}}\end{array}$ & $\begin{array}{c}\text { Velocity } \\
\text { Pressure } \\
\left.\text { p (1b/ft }{ }^{2}\right)^{c}\end{array}$ & $\begin{array}{c}\text { Wind Speed } \\
\mathrm{V} \\
(\mathrm{mph})\end{array}$ & $\begin{array}{l}\text { Velocity } \\
\text { Pressure } \\
q\left(1 \mathrm{~b} / \mathrm{ft} \mathrm{t}^{2}\right)\end{array}$ & $\begin{array}{c}\text { Wind Speed } \\
\mathbf{V} \\
(\mathrm{mph})\end{array}$ & $\begin{array}{l}\text { Velocity } \\
\text { Pressure } \\
q\left(1 b / f t^{2}\right)\end{array}$ \\
\hline 0 & 0 & 0 & 0 & 0 & 0 & 0 \\
\hline 10 & 59.8 & 9.15 & 39.3 & 3.95 & 21.4 & 1.17 \\
\hline 15 & 63.4 & 10.29 & 43.0 & 4.73 & 24.5 & 1.56 \\
\hline 20 & 66.1 & 11.19 & 45.8 & 5.37 & 27.0 & 1.87 \\
\hline 30 & 70.0 & 12.54 & 50.1 & 6.43 & 30.90 & 2.44 \\
\hline 50 & 75.3 & 14.52 & 56.2 & 8.09 & 36.6 & 3.43 \\
\hline 100 & 83.1 & 17.68 & 65.5 & 10.98 & 46.2 & 5.46 \\
\hline 200 & 91.8 & 21.57 & 76.4 & 14.94 & 58.2 & 8.67 \\
\hline 300 & 97.3 & 24.24 & 83.6 & 17.89 & 66.60 & 11.36 \\
\hline 400 & 101.4 & 26.32 & 89.2 & 20.37 & 73.3 & 13.75 \\
\hline 500 & 104.6 & 28.01 & 93.7 & 22.48 & 79.0 & 15.98 \\
\hline 600 & 107.4 & 29.53 & 97.6 & 24.39 & 83.9 & 18.02 \\
\hline 700 & 109.8 & 30.86 & 100.9 & 26.06 & 88.3 & 19.96 \\
\hline 800 & 111.9 & 32.06 & 104.0 & 27.69 & 92.3 & 21.81 \\
\hline 900 & 113.8 & 33.15 & 106.8 & 29.20 & 96.0 & 23.59 \\
\hline 1000 & & & 109.3 & 30.58 & 99.4 & 25.29 \\
\hline 1100 & & & 111.6 & 31.88 & 102.6 & 26.95 \\
\hline 1200 & & & 113.8 & 33.15 & 105.7 & 28.60 \\
\hline 1300 & & & & & 108.5 & 30.14 \\
\hline 1400 & & & & & 111.2 & 31.66 \\
\hline 1500 & & & & & 113.8 & 33.15 \\
\hline
\end{tabular}

${ }^{\mathrm{a}}$ To convert to $\mathrm{m}$, multiply by 0.3048 .

$\mathrm{b}_{\text {To }}$ convert to $\mathrm{m} / \mathrm{s}$, multiply by 0.447 .

$\mathrm{C}_{\text {To }}$ convert to $\mathrm{Pa}$, multiply by 47.88 . 
Table 2-5. Variation of Wind Velocity with Height, $\mathrm{U}_{30}=90 \mathrm{mph}(40 \mathrm{~m} / \mathrm{s})$

\begin{tabular}{|c|c|c|c|c|c|c|}
\hline \multirow{2}{*}{$\begin{array}{l}\text { Elevation } \\
(\mathrm{ft})^{\mathrm{a}}\end{array}$} & \multicolumn{2}{|c|}{ Exposure C } & \multicolumn{2}{|c|}{ Exposure B } & \multicolumn{2}{|c|}{ Exposure A } \\
\hline & $\begin{array}{c}\text { Wind Speed } \\
V \\
(m p h)^{b}\end{array}$ & $\begin{array}{c}\text { Velocity } \\
\text { Pressure } \\
q \quad\left(1 b / \mathrm{ft}^{2}\right)^{c}\end{array}$ & $\begin{array}{c}\text { Wind Speed } \\
\mathrm{V} \\
(\mathrm{mph})\end{array}$ & $\begin{array}{r}\text { Velocity } \\
\text { Pressure } \\
q\left(1 \mathrm{~b} / \mathrm{ft}^{2}\right)\end{array}$ & $\begin{array}{c}\text { Wind Speed } \\
\mathbf{V} \\
(\mathrm{mph})\end{array}$ & $\begin{array}{l}\text { Velocity } \\
\text { Pressure } \\
q\left(1 \mathrm{~b} / \mathrm{ft}^{2}\right)\end{array}$ \\
\hline 0 & 0 & 0 & 0 & 0 & 0 & 0 \\
\hline 10 & 77.0 & 15.18 & 50.5 & 6.53 & 27.5 & 1.94 \\
\hline 15 & 81.6 & 17.05 & 55.3 & 7.83 & 31.5 & 2.54 \\
\hline 20 & 85.0 & 18.05 & 58.9 & 8.88 & 34.7 & 3.08 \\
\hline 25 & 87.7 & 19.69 & 61.9 & 9.81 & 37.4 & 3.58 \\
\hline 30 & 90.0 & 20.74 & 64.5 & 10.65 & 39.7 & 4.03 \\
\hline 40 & 93.8 & 22.52 & 68.7 & 12.08 & 43.7 & 4.89 \\
\hline 50 & 96.1 & 23.64 & 72.2 & 13.34 & 47.1 & 5.68 \\
\hline 75 & 102.6 & 26.95 & 79.0 & 15.98 & 53.9 & 7.44 \\
\hline 100 & 106.9 & 29.25 & 84.2 & 18.15 & 59.3 & 9.00 \\
\hline 200 & 118.0 & 35.65 & 98.3 & 24.74 & 74.8 & 14.32 \\
\hline 500 & 134.5 & 46.31 & 120.5 & 37.17 & 101.5 & 26.37 \\
\hline 700 & 141.2 & 51.04 & 129.8 & 43.25 & 113.5 & 32.98 \\
\hline 900 & 146.3 & 54.79 & 137.3 & 48.26 & 123.4 & 38.98 \\
\hline 1200 & & & 146.3 & 54.79 & 135.8 & 47.21 \\
\hline 1500 & & & & & 146.3 & 54.79 \\
\hline
\end{tabular}

$\mathrm{a}_{\text {To }}$ convert to $\mathrm{m}$, multiply by 0.3048 .

$\mathrm{b}_{\text {To }}$ convert to $\mathrm{m} / \mathrm{s}$, multiply by 0.447 .

$\mathrm{c}_{\text {To }}$ convert to $\mathrm{Pa}$, multiply by 47.88 .

Task Committee (TC) [23]. The results are shown in Tables 2-7 and 2-8. They are also presented graphically in Figures 2-8 and 2-9.

The ratios of $C_{f}$ (code)/ $C_{f}$ (TC) and $C_{f}$ (code)/ $C_{f}$ (heliostat) indicate that the code values, within the range of the angles of attack, are generally $10 \%$ to $25 \%$ higher for $\lambda=1.0$. For $\lambda=3.0$, they are $22 \%$ to $25 \%$ higher. Thus the code gives an overestimate of the wind loads for the flow past an inclined flat plate. The values of $C_{f}$ estimated by using the Task Committee guidelines compare favorably with the experimental results of the full-scale heliostat resting. Figures 2-8 and 2-9 show that the ANSI coefficient $C_{f}$ is moderately conservative if the angle of artack is less than $15^{\circ}$ and that 1 is somewhat more conservative ac higher angles of attack. For longer plates, the code values are generally more conservative. 


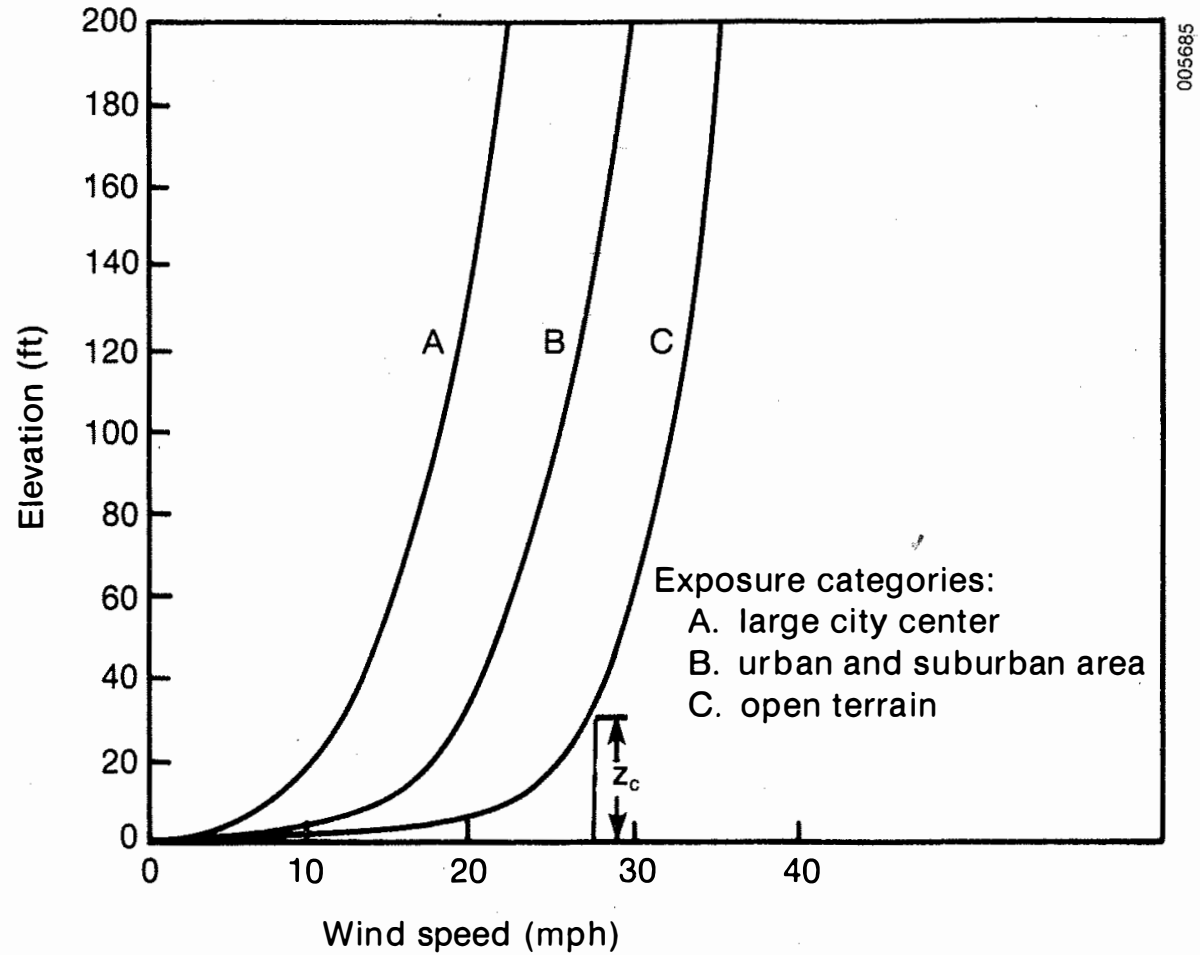

Figure 2-2. Variation of Wind Speed with Elevation, $\left(U_{30}\right)_{C}=27 \mathrm{mph}$

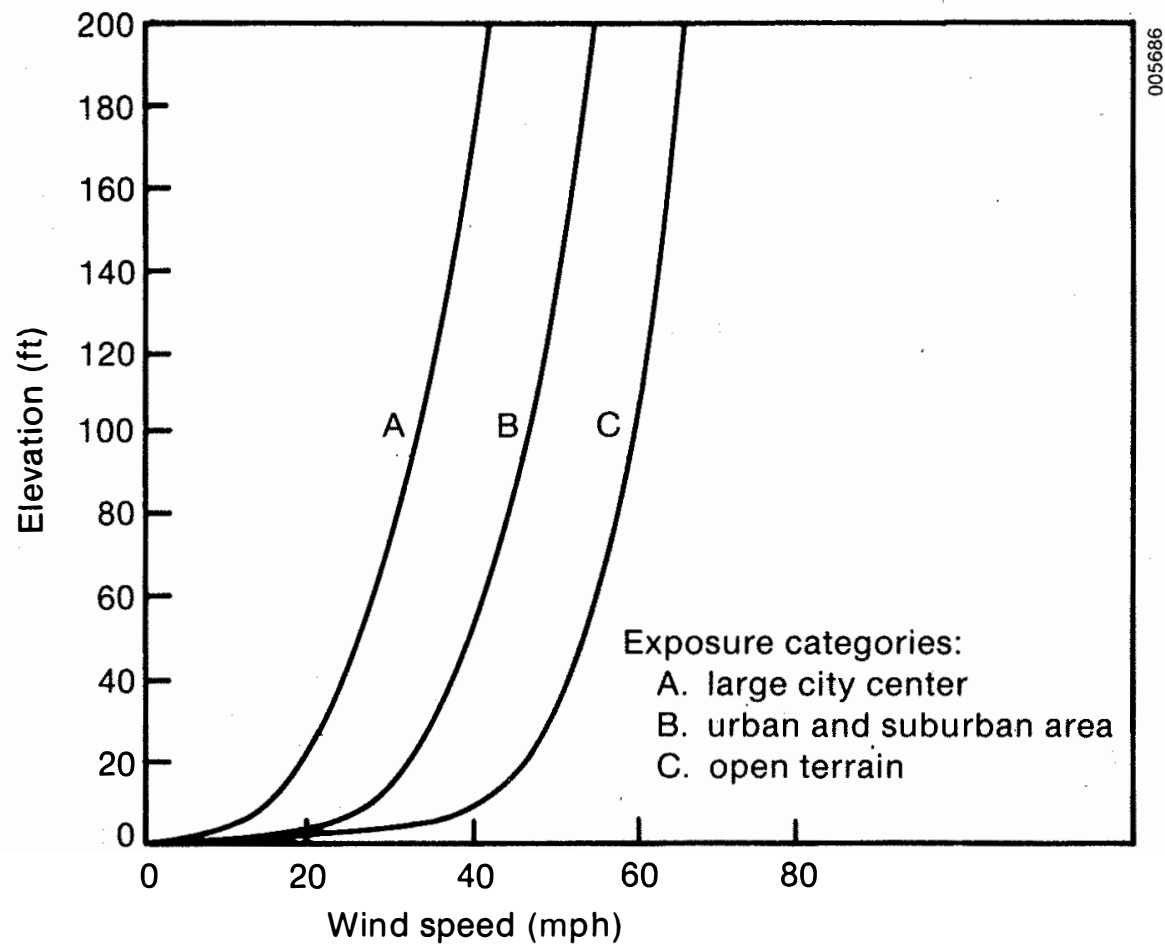

Figure 2-3. Variation of Wind Speed with Elevation, $\left(\mathrm{U}_{30}\right)_{C}=50 \mathrm{mph}$ 


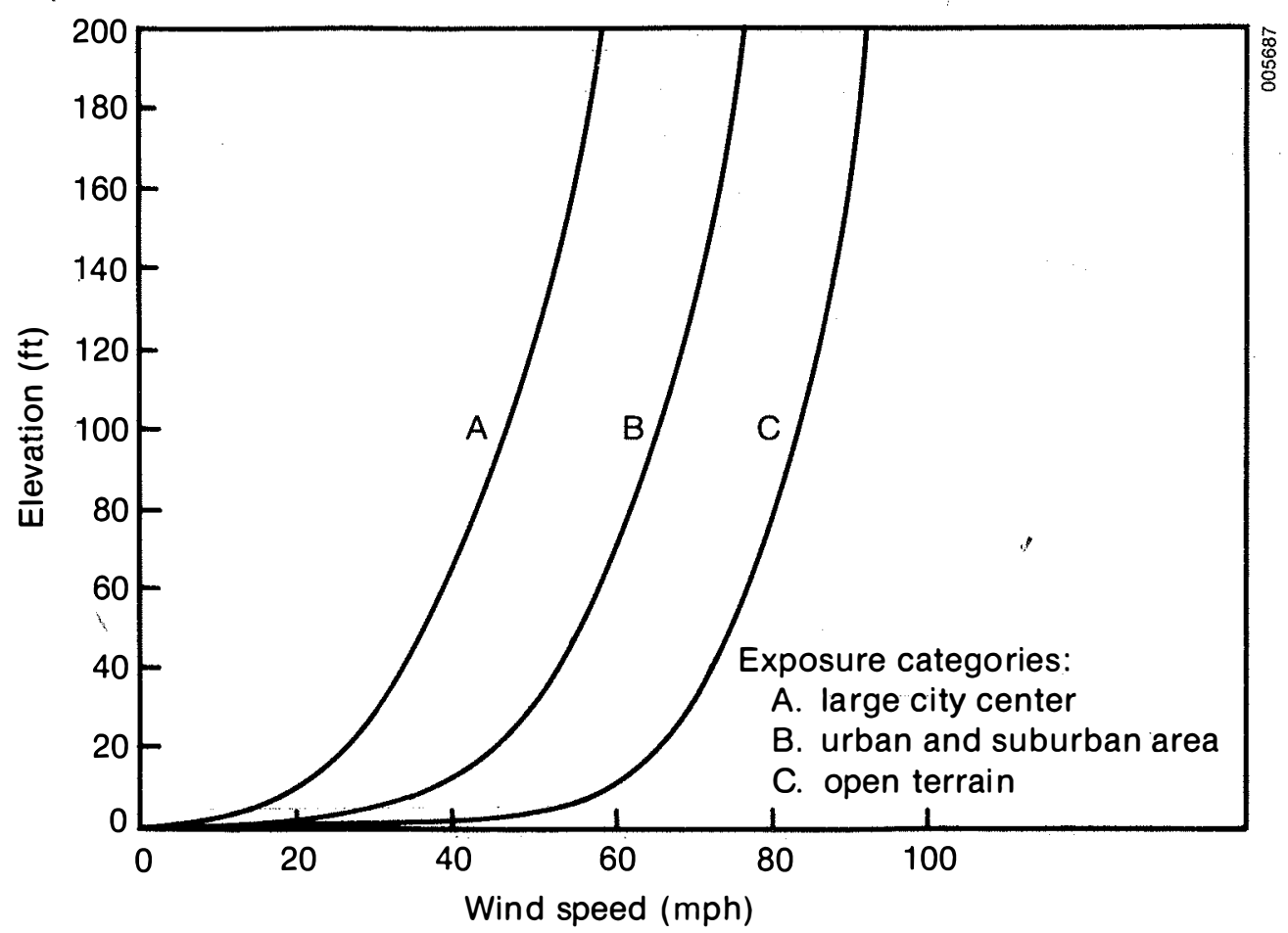

Figure 2-4. Variation of Wind Speed with Elevation, $\left(U_{30}\right)_{C}=70 \mathrm{mph}$

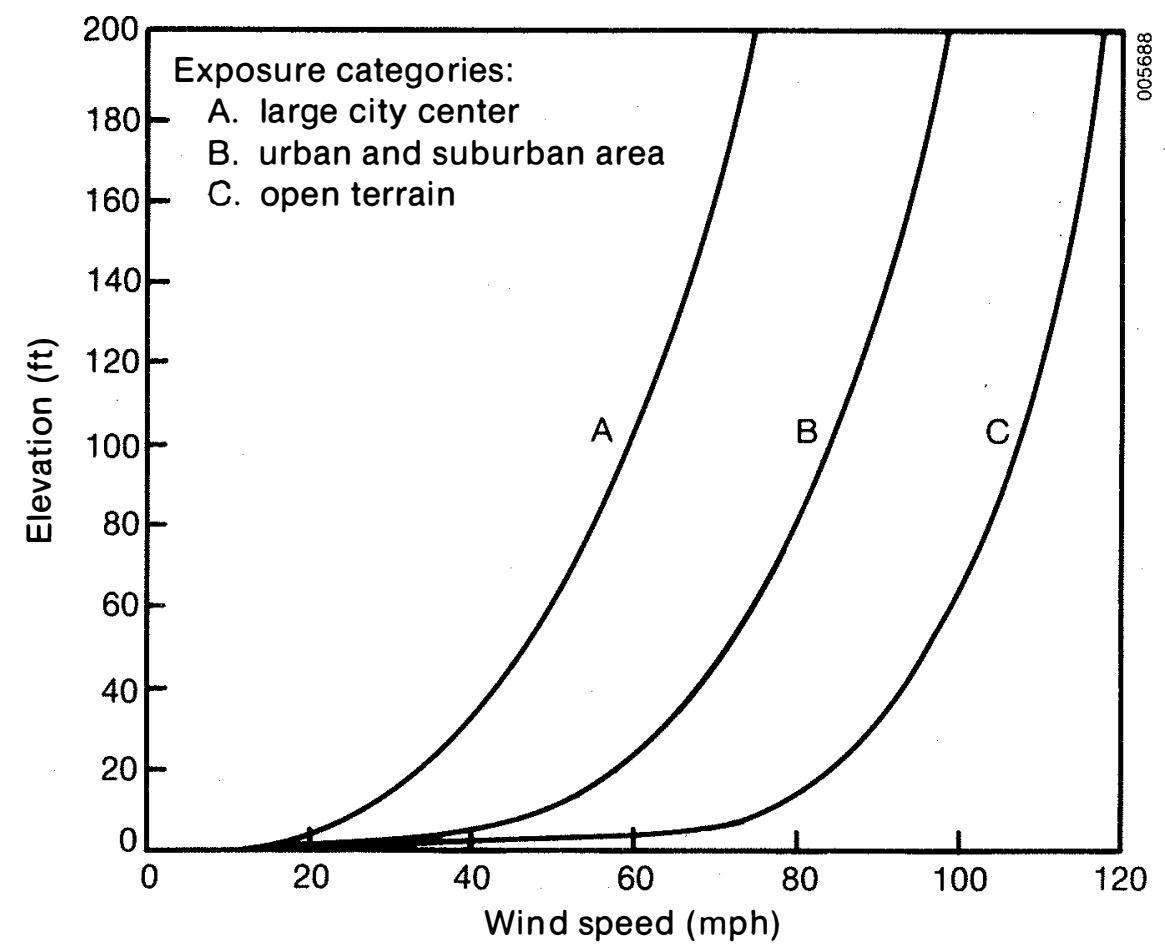

Figure 2-5. Variation of Wind Speed with Elevation, $\left(U_{30}\right)_{C}=90 \mathrm{mph}$ 
Table 2-6. Velocity Pressure

\begin{tabular}{cccc}
\hline $\begin{array}{c}\text { Wind Velocity } \\
\mathrm{V}(\mathrm{mph})^{\mathrm{a}}\end{array}$ & $\begin{array}{c}\text { Dynamic Pressure } \\
0.00256 \mathrm{~V}^{2}\left(\mathrm{~b} / \mathrm{ft}^{2}\right)^{\mathrm{b}}\end{array}$ & $\begin{array}{c}\text { Wind Velocity } \\
\mathrm{V}(\mathrm{mph})\end{array}$ & $\begin{array}{c}\text { Dynamic Pressure } \\
0.00256 \mathrm{~V}^{2}\left(1 \mathrm{~b} / \mathrm{ft}^{2}\right)\end{array}$ \\
\hline 10 & 0.26 & 220 & 124 \\
20 & 1.0 & 240 & 147 \\
30 & 2.5 & 260 & 201 \\
40 & 4.1 & 280 & 230 \\
50 & 6.4 & 300 & \\
60 & 9.2 & & \\
70 & 12.6 & & \\
80 & 16.4 & & \\
90 & 20.7 & & \\
100 & 25.6 & & \\
120 & 37.0 & & \\
140 & 50.2 & & \\
160 & 65.5 & & \\
180 & 83.0 & & \\
200 & 102.4 & & \\
& & & \\
\end{tabular}

$a_{\text {To }}$ convert to $\mathrm{m} / \mathrm{s}$, multiply by 0.447 .

$\mathrm{b}_{\mathrm{T}}$ o convert to $\mathrm{Pa}$, multiply by 47.88 .

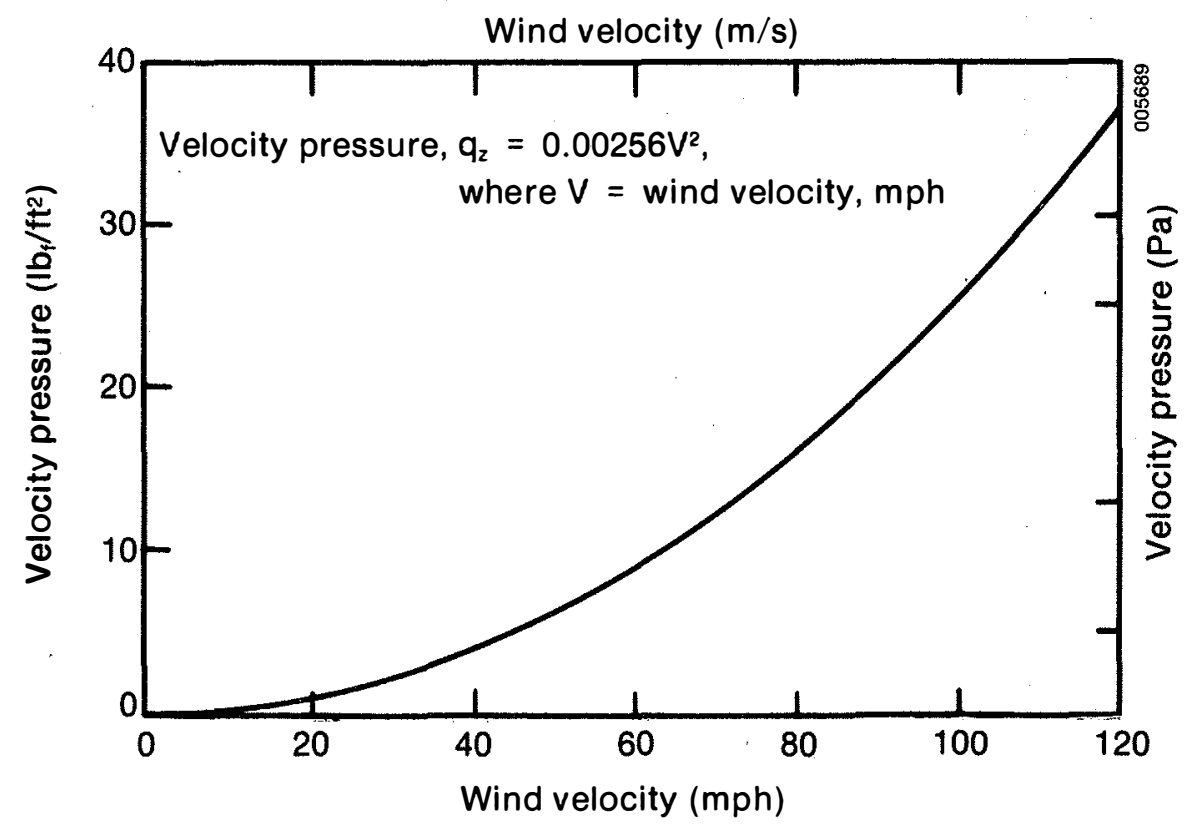

Figure 2-6. Variation of Velocity Pressure with Wind Velocity 

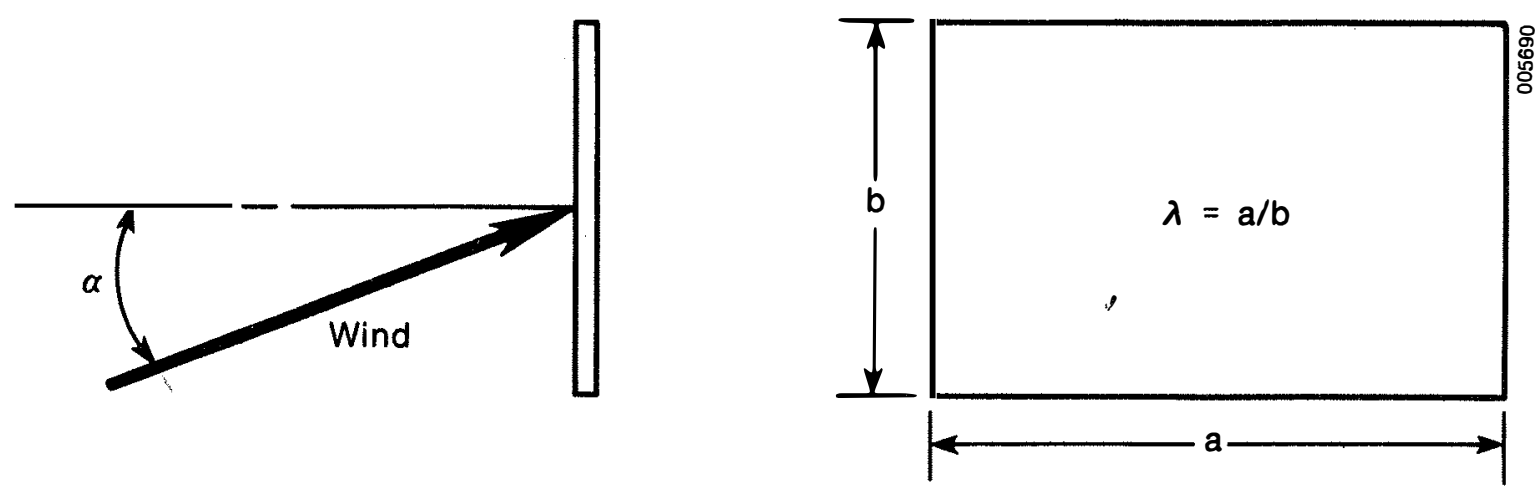

Figure 2-7. A Geonetry for Flow past a Flat Plate

Table 2-7. $C_{f}$ for Flow past a Flat Plate, ${ }^{a}$ Aspect Rat1o, $\lambda=1.0$

\begin{tabular}{cccccc}
\hline $\begin{array}{c}\text { Angle of Attack } \alpha \\
\text { (deg) }\end{array}$ & $\begin{array}{c}\mathrm{C}_{\mathrm{f}} \\
\text { (Code) }\end{array}$ & $\begin{array}{c}\mathrm{C}_{\mathrm{f}} \\
\text { Task Comm. }\end{array}$ & $\begin{array}{c}\mathrm{C}_{\mathrm{f}_{\text {code }}} \\
\mathrm{C}_{\mathrm{f}_{\mathrm{TC}}}\end{array}$ & $\begin{array}{c}\mathrm{C}_{\mathrm{f}} \\
\text { Fellostat } \\
\text { Full-Scale } \\
\text { Test }\end{array}$ & $\frac{\mathrm{C}_{\mathrm{f}_{\text {code }}}}{\mathrm{C}_{\mathrm{f}_{\text {hellostat }}}}$ \\
\hline 0 & 0 & 0 & 0 & 0 & 0 \\
10 & 0.45 & 0.39 & 1.15 & 0.39 & 1.15 \\
15 & 0.70 & 0.62 & 1.13 & 0.64 & 1.09 \\
20 & 0.90 & 0.84 & 1.07 & 0.84 & 1.07 \\
25 & 1.15 & 0.96 & 1.20 & 0.98 & 1.17 \\
30 & 1.30 & 1.04 & 1.25 & 1.07 & 1.21 \\
\hline
\end{tabular}

${ }^{a}$ Code values are given only up to $\alpha=30^{\circ}$.

bsee Peglow [16]. 
Table 2-8. $C_{f}$ for Flow past a Flat Plate, Aspect $\operatorname{Rat10}, \lambda=3.0$

\begin{tabular}{cccc}
\hline $\begin{array}{c}\text { Angle of Attack } \alpha \\
\text { (deg) }\end{array}$ & $\begin{array}{c}\mathrm{C}_{\mathrm{f}} \\
\text { (Code) }\end{array}$ & $\begin{array}{c}\mathrm{C}_{\mathrm{f}} \\
\text { Task Comm. }\end{array}$ & $\frac{\mathrm{C}_{\mathrm{f}_{\text {code }}}}{\mathrm{C}_{\mathrm{f}_{\mathrm{TC}}}}$ \\
\hline 0 & 0 & 0 & 0 \\
10 & 0.70 & 0.57 & 1.23 \\
15 & 0.90 & 0.72 & 1.25 \\
20 & 0.95 & 0.78 & 1.22 \\
25 & 1.05 & 0.84 & 1.25 \\
30 & 1.10 & 0.88 & 1.25 \\
\hline
\end{tabular}

An important feature of the ANSI code is that the minimum angle of attack is $10^{\circ}$. The code does not consider any angle of attack less than $10^{\circ}$.

The selection of the angle of attack, particularly in the stowed horizontal position of the hellostat, must be made with careful consideration of the meteorological and turbulence characteristics of the high speed air flow. Normally the air flows horizontally over the surface of the earth with a relatively small vertical component. The vertical component arises from two basic sources: surface roughness and instabilities in the air caused by temperature, density, and molsture differences. The first source is essentlally mechanical and the second is thermodynamic. In the present study, our primary concern is mainly for the situation when survival requirements (90-mph winds) dictate that the hellostats be placed in the horizontal stow position. Such

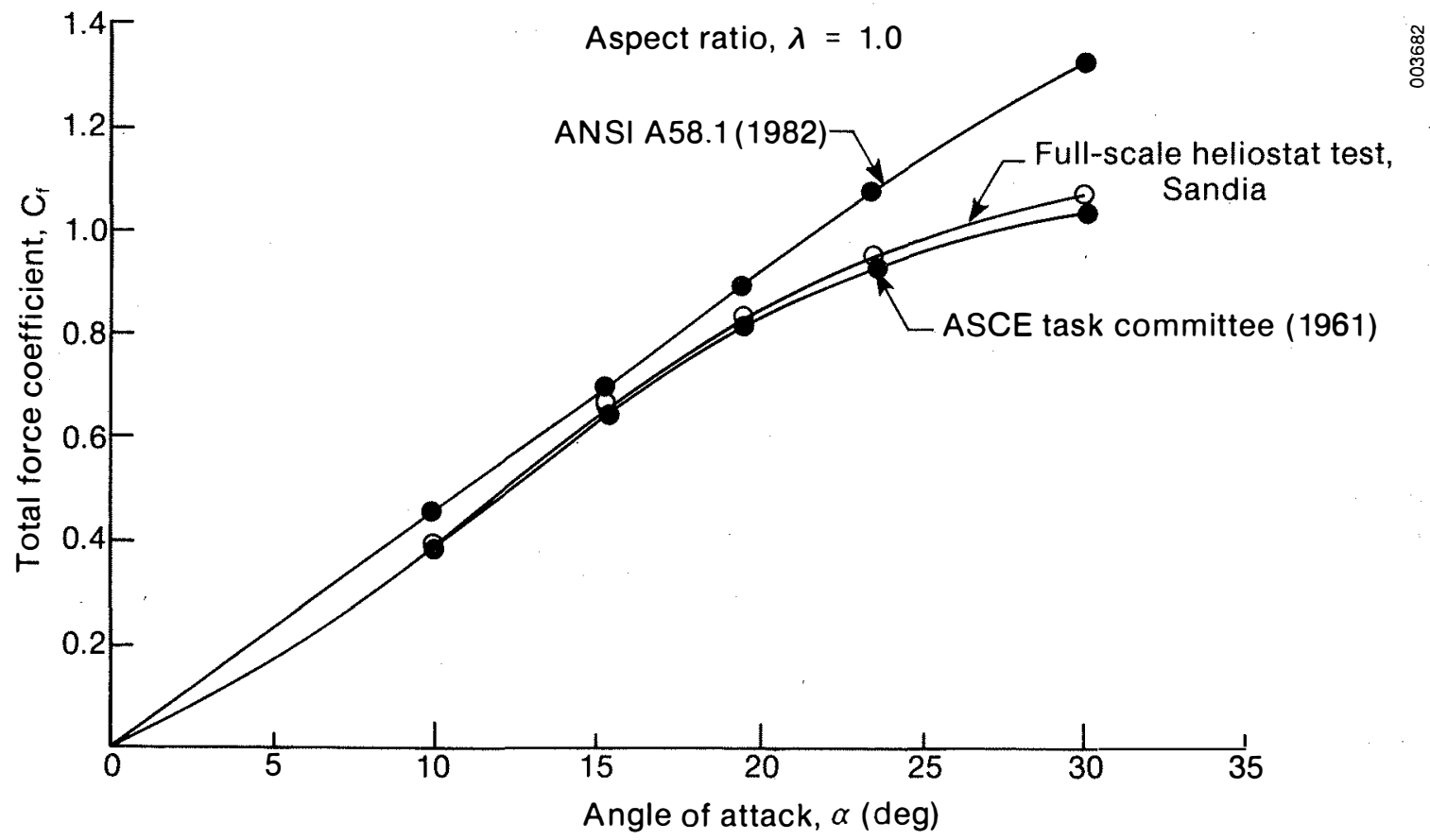

Figure 2-8. Variation of Force Coefficient with Angle of Attack, Aspect Ratio, $\lambda=1.0$ 


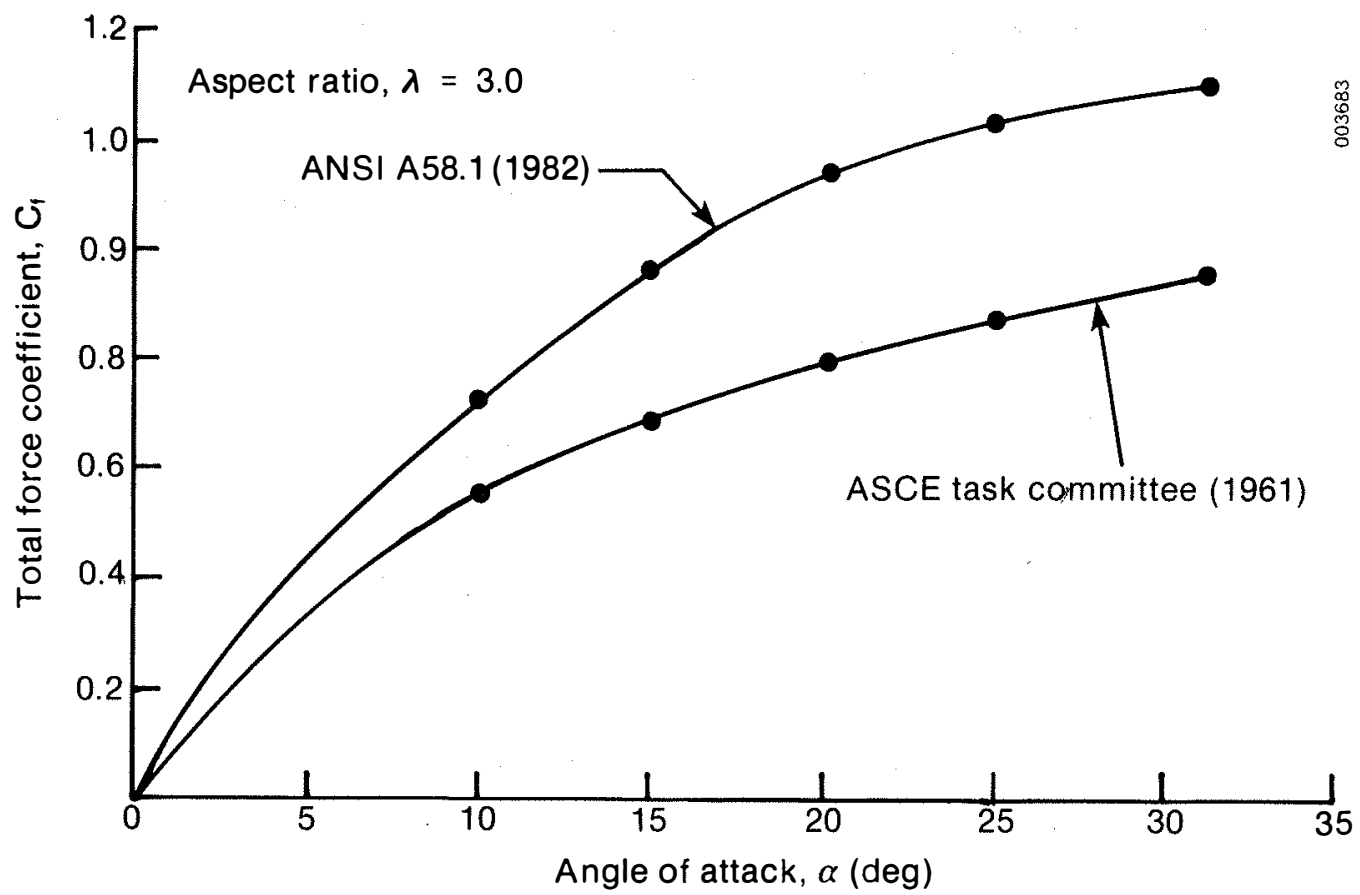

Figure 2-9. Variation of Force Coefficient with Angle of Attack, Aspect $\operatorname{Rat10}, \lambda=3.0$

high wind generally occurs during neutral atmospheric stability, and there is little vertical movement of air caused by thermodynamic effects. It appears that the dominant causes of the vertical component of air velocity are turbulence effects. The force of turbulence-induced vertical fluctuating air acting on the horizontal hellostat can be estimated from the knowledge of the turbulent energy spectra of the approach wind.

\subsection{ATMOSPEERIC TURBULENCE SPECTRA}

The random fluctuations of velocity in a turbulent flow passing a point in the flow fleld may be caused by the superposition of the local vortices or eddies, each with a random motion of frequency $n$ (alternatively of wave number $k$ ). We can approximate the total kinetic energy of the turbulent motion by summing the contributions of each eddy in the flow. When the equations of motion of turbulent flow are appropriately transformed and analyzed, it can be shown that the inertial transfer of energy from the larger eddies to the smaller eddies takes place; the viscous dissipation takes place primarily in the smallest eddies through shear deformations. The cascade process of kinetic energy transfer from the larger eddies to the smaller ones, and ultimately energy dissipation into heat, is the basic postulate of Kolmogorov's hypothesis.

Measurements of turbulent spectra in the surface layer of the atmosphere substantiate the validity of the assumptions regarding the turbulent energy transfer mechanism. In an idealized horizontally homogeneous, neutrally stable flow, the energy production rate is approximately balanced by the energy dissipation rate. 
The wind velocity varies randomly with time. As a result, the wind pressures on the surface of the structure are not steady; they also vary with time. The mean square dynamic pressure is related to the mean square longltudinal velocity fluctuations, which implies that the pressure spectrum is proportional to the spectrum of the longitudinal velocity. The spectrum of dynamic pressure can be predicted from the known longitudinal velocity spectrum.

The estimation of "gust response factor" used to determine the wind force on the structure is based on the design methodology developed by Vellozzi and Cohen [6]. The methodology uses the results of the power spectrum analysis of the dynamic structural response of simple linear single one degree of freedom system with viscous damping and measured wind gust spectra and gust correlation coefficient. The various turbulent wind spectra, commonly used in the study of lower atmosphere, are compared to assess the energy spectra used in the ANSI bullding code.

The spectrum $S(z, n)$ of the longitudinal velocity fluctuations in the inertial subrange can be expressed in the following normalized form [24]:

$$
\frac{\mathrm{n} S(\mathrm{z}, \mathrm{n})}{\mathrm{U}_{*}^{2}}=0.26 \mathrm{f}^{-2 / 3}
$$

where

$$
\begin{array}{ll}
\mathrm{f} & =\frac{\mathrm{n} Z}{\mathrm{U}(\mathrm{z})}, \mathrm{n}=\text { frequency } \\
\mathrm{U}_{*} & =\text { friction velocity } \\
\mathrm{z} & =\text { elevation } \\
\mathrm{U}(\mathrm{z}) & =\text { mean velocity at height } \mathrm{z} .
\end{array}
$$

The left-hand member of Eq. 2-15 is called the reduced spectrum of the longitudinal velocity fluctuations and is a function of height. Simiu [25] considers Eq. 2-15 a good representation of spectra in the high-frequency range and suggests using it for $\mathrm{f}>0.2$.

The longitudinal energy spectra currently employed in the ANSI A58.1-1982 bullding code can be expressed by the following empirical relation [25]:

$$
\frac{\mathrm{n} S(\mathrm{z}, \mathrm{n})}{\mathrm{U}_{*}^{2}}=\frac{4 \mathrm{x}^{2}}{\left(1+\mathrm{x}^{2}\right)^{4 / 3}},
$$

where

$$
\begin{array}{ll}
\mathrm{x} & =\frac{1200 \mathrm{n}}{\mathrm{U}(10)} \\
\mathrm{U}(10) & =\text { mean wind speed at helght } 10 \mathrm{~m}(\mathrm{mph}, \mathrm{m} / \mathrm{s}) .
\end{array}
$$

Equation 2-16 was obtained by averaging the results of the ineasurements at various heights and does not, therefore, show the dependence of spectra on height. 
In the low-frequency range the energy spectra cannot be described by a universal relation. Kaimal et al. [26] considered the limiting value of the spectra as $f$ approaches zero, and the product $n S(z, n)$ reaches a maximum value at $f=f_{m}$ such that $0<f_{m}<f_{S}$. Equation 2-15 is valid beyond the value of $f=f_{S}$. Kaimal et al. [26] proposed the following empirical relation for the longitudinal spectra in the low frequency range:

$$
\frac{\mathrm{n} S(z, n)}{U_{*}^{2}}=\frac{200 \mathrm{f}}{(1+50 \mathrm{f})^{5 / 3}} \text {. }
$$

Equation 2-17 approximates closely the spectrum in the higher frequency range also, and Simiu [25] suggested using it for the entire spectrum.

The spectra that Lumly and Ponofsky [27] developed for the vertical and lateral velocity fluctuations in the lower surface layer of the atmosphere are given, respectively, by the empirical relations:

$$
\frac{\mathrm{nS}_{\mathrm{W}}(\mathrm{z}, \mathrm{n})}{\mathrm{U}_{*}^{2}}=\frac{3.36 \mathrm{f}}{(1+10 \mathrm{f})^{5 / 3}},
$$

and

$$
\frac{n S_{v}(n)}{U_{*}^{2}}=\frac{15 f}{(1+9.5 f)^{5 / 3}}
$$

Equation 2-16 was obtained by averaging results of measurements obtained at varlous helghts above the ground and does not reflect the dependence of spectra on helght. However, the dependence of spectra on height is clearly suggested by Davenport [28]. The spectral distribution in the lower frequency range has 1ittle influence on the structural response. However, the magnitude of the turbulent fluctuation components at the natural frequencles of the structure (or of one or more of its major elements) may affect its response significantly. Simiu [25] considered a wind velocity of $30 \mathrm{~m} / \mathrm{s}$ and a surface roughness $z_{0}=0.08 \mathrm{~m}$ and computed the longitudinal spectra in the frequency range of $0.001-0.5 \mathrm{~Hz}$ by using Eqs. 2-16 and 2-17. He considered helghts $z=100.0 \mathrm{~m}, 200.0 \mathrm{~m}$, and $300.0 \mathrm{~m}$. The comparison showed that the expression currently used in bullding codes overestimated the longitudinal spectra of turbulence in the higher frequency range by as much as $100 \%-400 \%$.

To compare the spectra obtained using Eqs. 2-15 through 2-19, computations were made for two wind velocities, namely $U(z)=44.73 \mathrm{mph}$ and $U(z)=90.0 \mathrm{mph}$ at a height of $z=30.0 \mathrm{ft}$. This height was chosen to conform to the requirement of the ANSI code. Figure 2-10 shows the longitudinal spectra computed by Eqs. 2-15, 2-16, and 2-17 for wind velocity $U=44.73 \mathrm{mph}(20.0$ $\mathrm{m} / \mathrm{s})$. The building code spectra overestimate the Kaimal spectra in the frequency range of $0.007-0.08 \mathrm{~Hz}$ and underestimate beyond the frequency $\mathrm{n}=0.08 \mathrm{~Hz}$. Figure 2-11 shows the longitudinal, lateral, and vertical spectra of turbulence of $44.73-\mathrm{mph}$ wind at a helght of $30.0 \mathrm{ft}$. At frequency $\mathrm{n}=1.0 \mathrm{~Hz}$, the local isotropy is realized. For frequency less than $1.0 \mathrm{~Hz}$, the vertical spectral energy content is less than these for the longitudinal and lateral components. Figure 2-12 shows the energy spectra of turbulence for a $90.0-\mathrm{mph}$ wind at an elevation of $30.0 \mathrm{ft}$. 


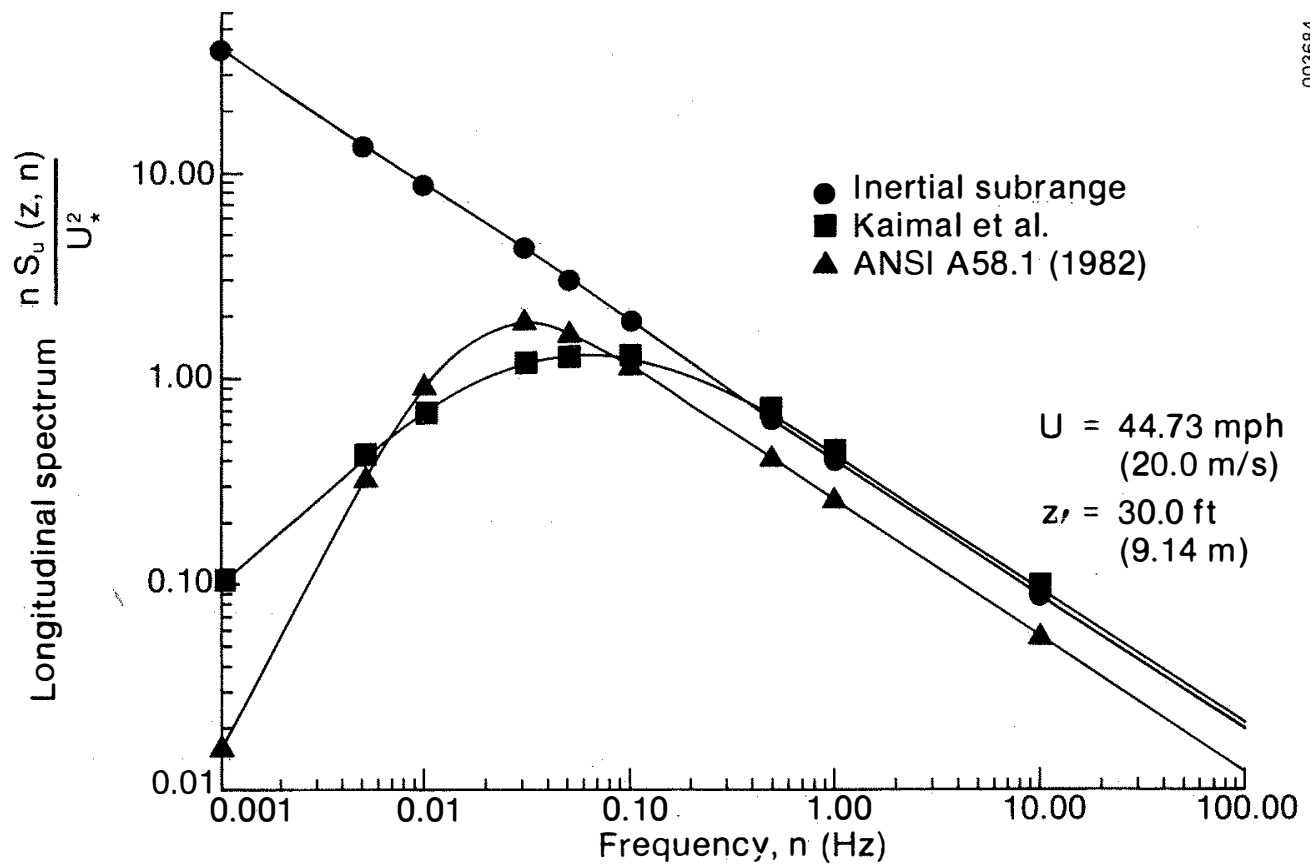

Figure 2-10. Longitudinal Turbulence Spectra, $\mathrm{U}=44.73 \mathrm{mph}(20.0 \mathrm{~m} / \mathrm{s})$

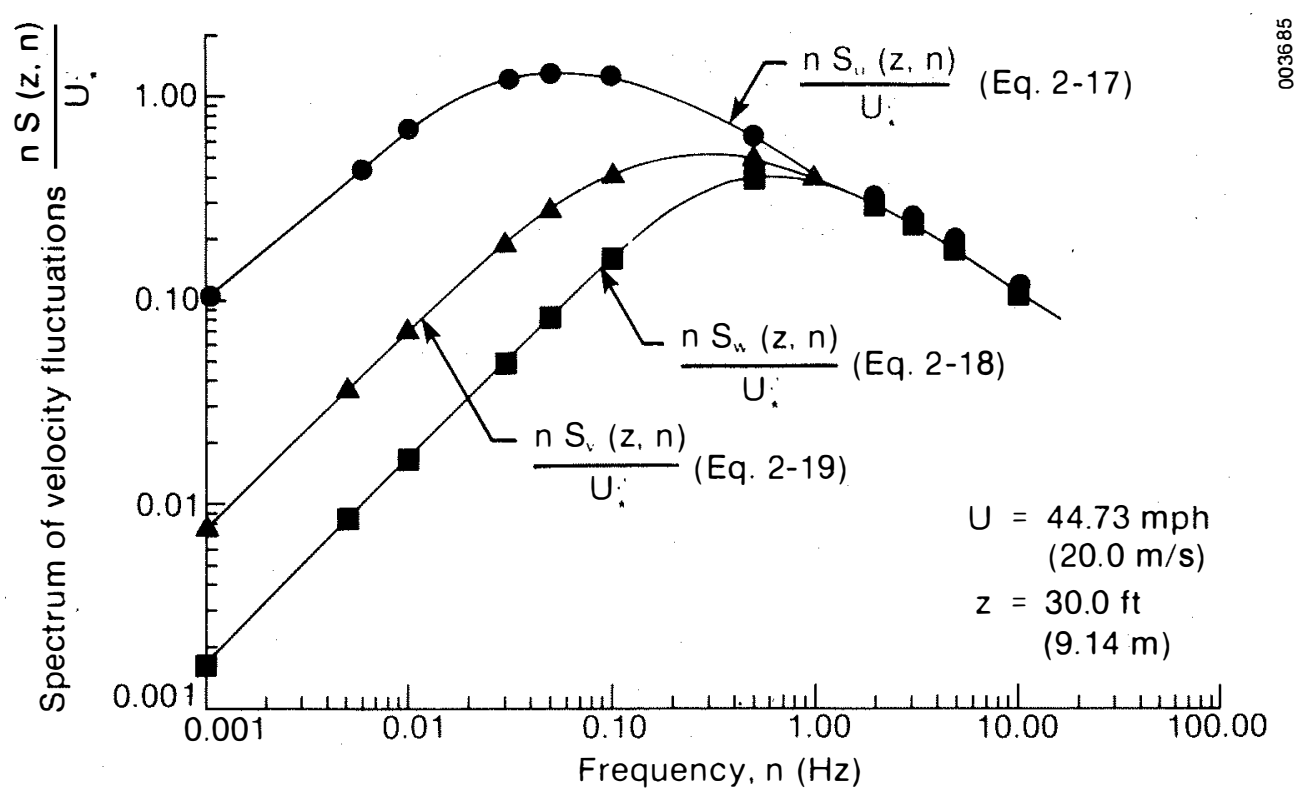

Figure 2-11. Turbulent Wind Spectra, $\mathrm{U}=44.73 \mathrm{mph}(20.0 \mathrm{~m} / \mathrm{s})$ 


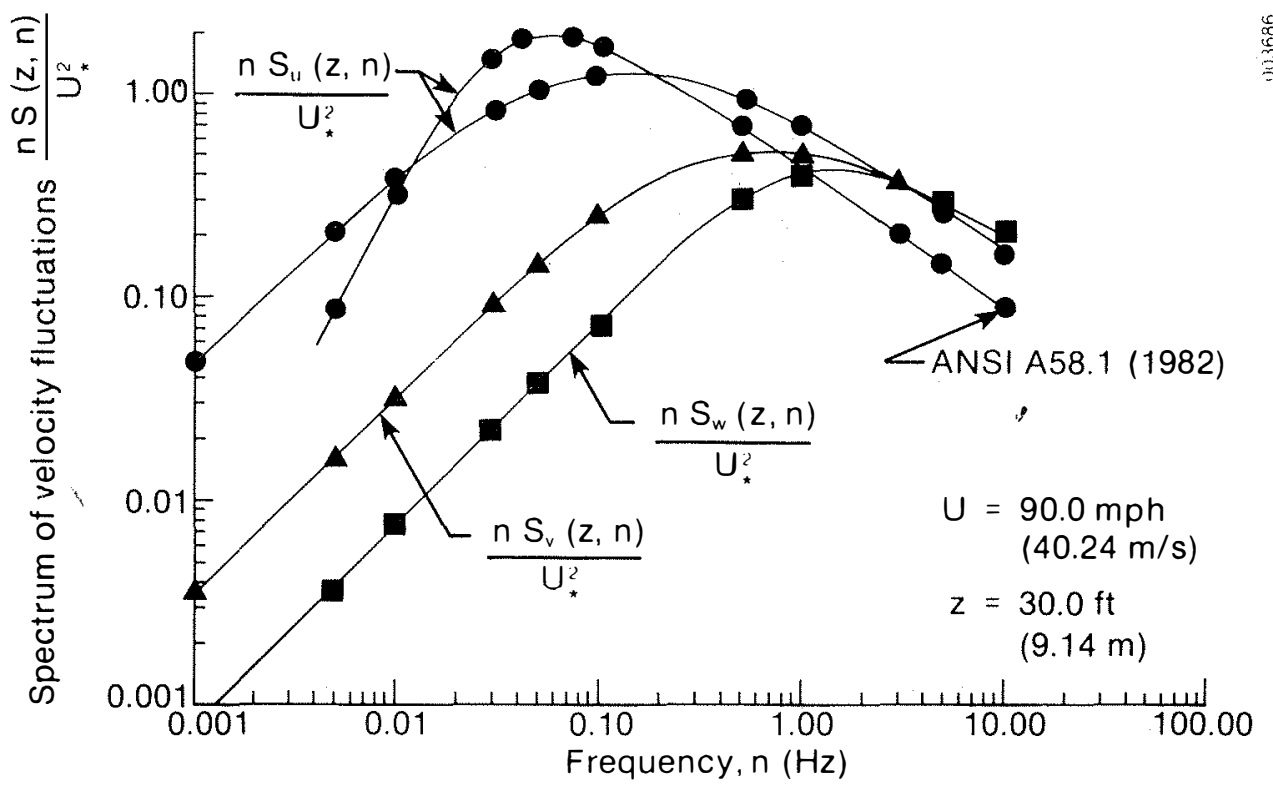

Figure 2-12. Turbulent Wind Spectra, $\mathrm{U}=90.0 \mathrm{mph}(40.24 \mathrm{~m} / \mathrm{s})$

\subsection{VARIATION IN WIND ANGLE FROM THE HORIZONTAL}

The vertical wind components fluctuate randomly at various rates. When the heliostats are stowed in a horizontal position, the effect of the longitudinal component of the wind velocity on the hellostats is relatively small. However, the peak angle of attack of the vertical turbulent component of wind velocity may have a significant effect on the structure. The angle of attack stipulated in the ANSI code is rather large. According to the code, the minimum angle of attack on a flat plate must be $10^{\circ}$.

The methodology developed by Daniels [29] is used to estimate the probable value of the peak angle of attack on the hellostat in the horizontal position. According to Daniels, the lateral spectra are the basis for determining the lateral angle of attack. Since the vertical spectral energy content is generally less than that of the lateral spectra, Daniels suggests that the angle of attack will give correct values at frequencies beyond $n=3.0 \mathrm{~Hz}$ if it is determined on the basis of the lateral spectra. The angle of attack will be somewhat overestimated for values of frequency less than $n=3.0 \mathrm{~Hz}$. Accordingly, the angles of attack for wind velocities of $30.0,50.0$, and $90.0 \mathrm{mph}$ at an elevation of $30.0 \mathrm{ft}$ are estimated. First, we determine the angle of attack for the lateral component of turbulent velocity. Then, by comparing the magnitude of the lateral and vertical spectra at their peak frequencles, we use a correction factor to estimate the angle of attack for the vertical component of the turbulent velocity. 
The along-wind spectra are represented by the curve marked "longitudinal," and across-wind spectra are represented by the curve marked "lateral." The longitudinal and lateral spectral values $S(\omega)$ at a frequency $\omega$ and height $z$ are given in the form of a dimensionless formula:

$$
\frac{\omega}{\beta} \frac{S(\omega)}{U_{*}^{2}}=\frac{c_{1} f / f_{m}}{\left\{\left[1+1.5\left(f / f_{m}\right) c_{2}\right] 5 / 3\right\} c_{2}},
$$

where

$$
\begin{gathered}
f=\frac{w z}{U(z)}, \\
f_{m}=c_{3}\left(z / z_{r}\right) c_{4}, \\
\beta=\left(\frac{z}{z_{r}}\right) c_{5},
\end{gathered}
$$

and

$$
U_{\dot{*}}=\frac{0.4 U(z)}{\ln \frac{z_{r}}{z_{0}}-\Psi}
$$

Daniels' velocity spectra for strong wind conditions are shown in Figure 2-13. In the above equations $z_{r}$ is the reference height equal to $60 \mathrm{ft}(18.3 \mathrm{~m})$ for the sites and the values of the constants suggested (shown in Table 2-9); $z_{0}$

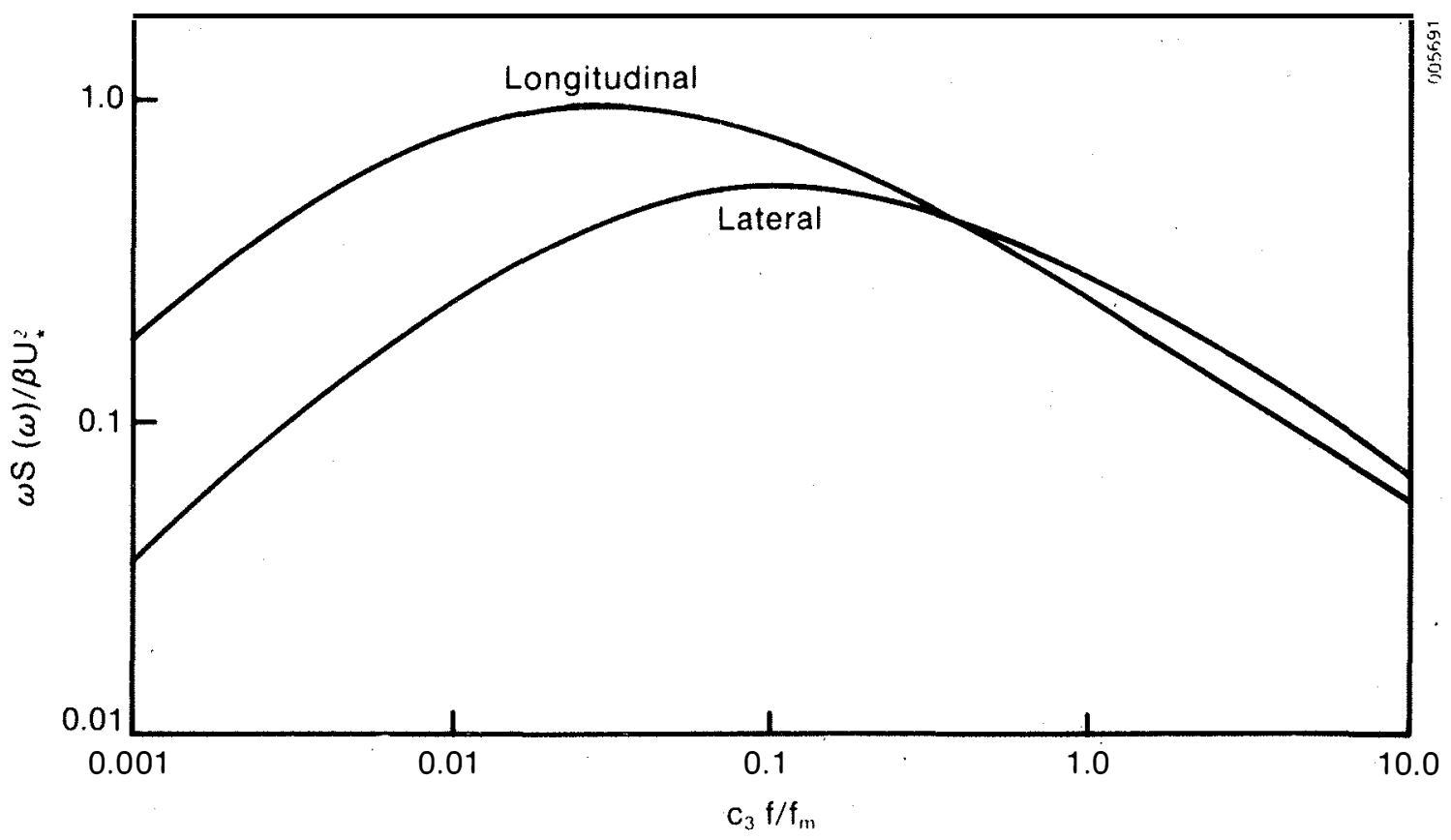

Figure 2-13. Strong Wind Velocity Spectra

Source: Ref. 29. 
Table 2-9. Dimensionless Constants for Longitudinal and Lateral Turbulence Spectra

\begin{tabular}{|c|c|c|c|c|c|}
\hline \multirow{2}{*}{ Condition } & \multicolumn{5}{|c|}{ Constant } \\
\hline & $c_{1}$ & $c_{2}$ & $c_{3}$ & $c_{4}$ & $c_{5}$ \\
\hline $\begin{array}{l}\text { Strong wind } \\
\text { (Longitudinal) }\end{array}$ & 6.198 & 0.845 & 0.03 & 1.00 & -0.63 \\
\hline $\begin{array}{l}\text { Strong wind } \\
\text { (Lateral) }\end{array}$ & 3.954 & 0.781 & 0.10 & 0.58 & -0.35 \\
\hline
\end{tabular}

Source: Ref. 29 .

is the surface roughness at the site; $\Psi$ is a stability parameter depending on the atmospheric stability; $U(z)$ is the mean longitudinal wind speed at a height $z$; and $c_{1}, c_{2}, c_{3}, c_{4}$, and $c_{5}$ are dimensionless site-specific constants. The parameters $\beta$ and $f_{m}$ account for helght effects and are used in normalizing the dimensionless quantities

$$
\frac{\omega S(\omega)}{\beta U_{*}^{2}} \text { and } \frac{c_{3} f}{f_{m}} \text {. }
$$

The following parameters are required to estimate the angle of attack for the lateral component of the turbulent fluctuating velocity: the elevation $Z$, the mean longitudinal wind speed $U(z)$ at that height, and the characteristic roughness length $z_{0}$ of the site. Using the relations given in Eq. 2-20, the values of the parameters $\beta, U_{*}$, and $f_{m}$ are computed. To estimate the amplitude of the lateral component of turbulent velocity $v_{0}$, a simple sinusoidal model is used. It can be assumed that

$$
v(t)=v_{0} \sin 2 \pi \omega t
$$

where

$$
\begin{aligned}
v_{0} & =\text { amplitude of lateral velocity } \\
\omega & =\text { frequency in } \mathrm{Hz} \\
t & =\operatorname{time}(\mathrm{s})
\end{aligned}
$$

The frequencles $\omega$ for low-frequency spectrum analysis are in the range of $0.01-1.0 \mathrm{~Hz}$. The peak frequency is approximately $\omega=0.1 \mathrm{~Hz}$ and is used to calculate the normalized frequency $f$. The normalized frequency parameter $0.1 \mathrm{f} / \mathrm{f}_{\mathrm{m}}$ on the abscissa of Figure 2-13 is then computed, and Figure 2-13 is used to get the value of $\frac{\omega S(\omega)}{\beta U^{2}}$ from the ordinate. For strong wind conditions, the stability parameter vanishes and is neglected in evaluating the friction of velocity $U_{*}$.

It can be shown [18] that at a particular frequency $\omega$, 


$$
\omega S(\omega)=\int_{0}^{2 \pi}[v(t)]^{2} \mathrm{dt}
$$

Using the relation of $v(t)$ from Eq. 2-21, Eq. 2-22 can be reduced to

$$
\omega S(\omega)=\frac{v_{0}^{2}}{2}
$$

Equation 2-23 is used to estimate the magnitude of peak lateral velocity:

$$
v_{0}=[2 \omega S(\omega)]^{1 / 2} \text {. }
$$

The angle of attack $\alpha_{v}$ for lateral fluctuating velocity is obtained from the following relationship:

$$
\alpha_{v}=\tan ^{-1}\left|\frac{v_{0}}{U(z)}\right| \text {. }
$$

Since the magnitude of lateral spectra is approximately 1.21 times larger than that of the vertical spectra, the amplitude of vertical fluctuating velocity $w_{0}$ is approximately equal to $0.91 v_{0}$. The angle of attack for the vertical component of fluctuation is given by

$$
\alpha_{w}=\tan ^{-1}\left(\frac{0.91 v_{0}}{U(z)}\right) \text {. }
$$

The angles of attack for lateral and vertical components of fluctuating velocities have been computed for each of three mean longitudinal velocities of $30.0,50.0$, and $90.0 \mathrm{mph}$ at the standard elevation of $30.0 \mathrm{ft}$ for various surface roughness lengths. The results are tabulated in Tables 2-10 and 2-11, and shown graphically in Figures 2-14 and 2-15. When the surface roughness length $z_{0}$ of a site is small, the values of the angle of attack are relatively less. The values increase as the roughness length increases. One interesting feature of the present analysis is that when the mean wind speed increases, the values of the angle of attack decrease. The design angle of attack.

Table 2-10. Variation of Angle of Attack due to Fluctuating Lateral Velocity

\begin{tabular}{lccc}
\multicolumn{1}{c}{$\begin{array}{c}\text { Angle of Attack, } \alpha \\
\text { Roughness } \\
\text { Height, } \mathrm{z}_{\mathrm{O}}\end{array}$} & $\mathrm{U}(30)=30.0 \mathrm{mph}$ & $\mathrm{U}(30)=50.0 \mathrm{mph}$ & $\mathrm{U}(30)=90.0 \mathrm{mph}$ \\
\cline { 2 - 5 } & 4.53 & 4.44 & 4.15 \\
$0.10 \mathrm{ft}(0.031 \mathrm{~m})$ & 4.039 & 3.96 & 3.70 \\
$0.20 \mathrm{ft}(0.061 \mathrm{~m})$ & 5.14 & 5.05 & 4.72 \\
$1.312 \mathrm{ft}(0.4 \mathrm{~m})$ & 6.73 & 6.61 & 6.19 \\
$1.968 \mathrm{ft}(0.60 \mathrm{~m})$ & 7.52 & 7.37 & 6.90 \\
$2.624 \mathrm{ft}(0.80 \mathrm{~m})$ & - & - & 7.53 \\
\hline
\end{tabular}


Table 2-11. Variation of Angle of Attack due to Fluctuating Vertical Velocity

\begin{tabular}{|c|c|c|c|c|c|}
\hline \multirow{2}{*}{$\begin{array}{l}\text { Roughness } \\
\text { Height, } z_{0}\end{array}$} & & Angle & $\begin{array}{l}\text { of Attack, } \\
\text { (deg) }\end{array}$ & $\alpha_{w}$ & \\
\hline & $\mathrm{U}(30)=30.0 \mathrm{mph}$ & $U(30)$ & $=50.0 \mathrm{mph}$ & $\mathrm{U}(30)$ & $=90.0 \mathrm{mph}$ \\
\hline $0.10 \mathrm{ft}(0.031 \mathrm{~m})$ & 3.68 & & 3.60 & & 3.37 \\
\hline $0.20 \mathrm{ft}(0.062 \mathrm{~m})$ & 4.12 & & 4.04 & & 3.78 \\
\hline $0.40 \mathrm{ft}(0.123 \mathrm{~m})$ & 4.68 & & 4.60 & , & 4.30 \\
\hline $1.312 \mathrm{ft}(0.40 \mathrm{~m})$ & 6.13 & & 6.02 & & 5.64 \\
\hline $1.968 \mathrm{ft}(0.06 \mathrm{~m})$ & 6.85 & & 6.71 & & 6.28 \\
\hline $2.624 \mathrm{ft}(0.80 \mathrm{~m})$ & - & & -- & & 6.86 \\
\hline
\end{tabular}

suggested by the ANSI A58.1-1982 code is $10^{\circ}$. The recent improved value of the angle of attack suggested by Murphy [14] is $6^{\circ}$.

The McDonne11 Douglas Astronautics Company (MDAC) [30] reported that a maximum of a $6.5^{\circ}$ angle of attack could be expected for high winds in gentle, rolling terrain with a roughness length of $4.0 \mathrm{~cm}$.

Vann [31] used Daniel's approach and estlinated the angle of at tack due to lateral fluctuations for wind velocity $U=30.0 \mathrm{mph}(13.41 \mathrm{~m} / \mathrm{s})$, at height $z=30 \mathrm{ft}$, for surface roughness $z_{0}=3.0 \mathrm{ft}$. He considered the lateral spectra as representative of vertical spectra. The estimated peak angle of attack

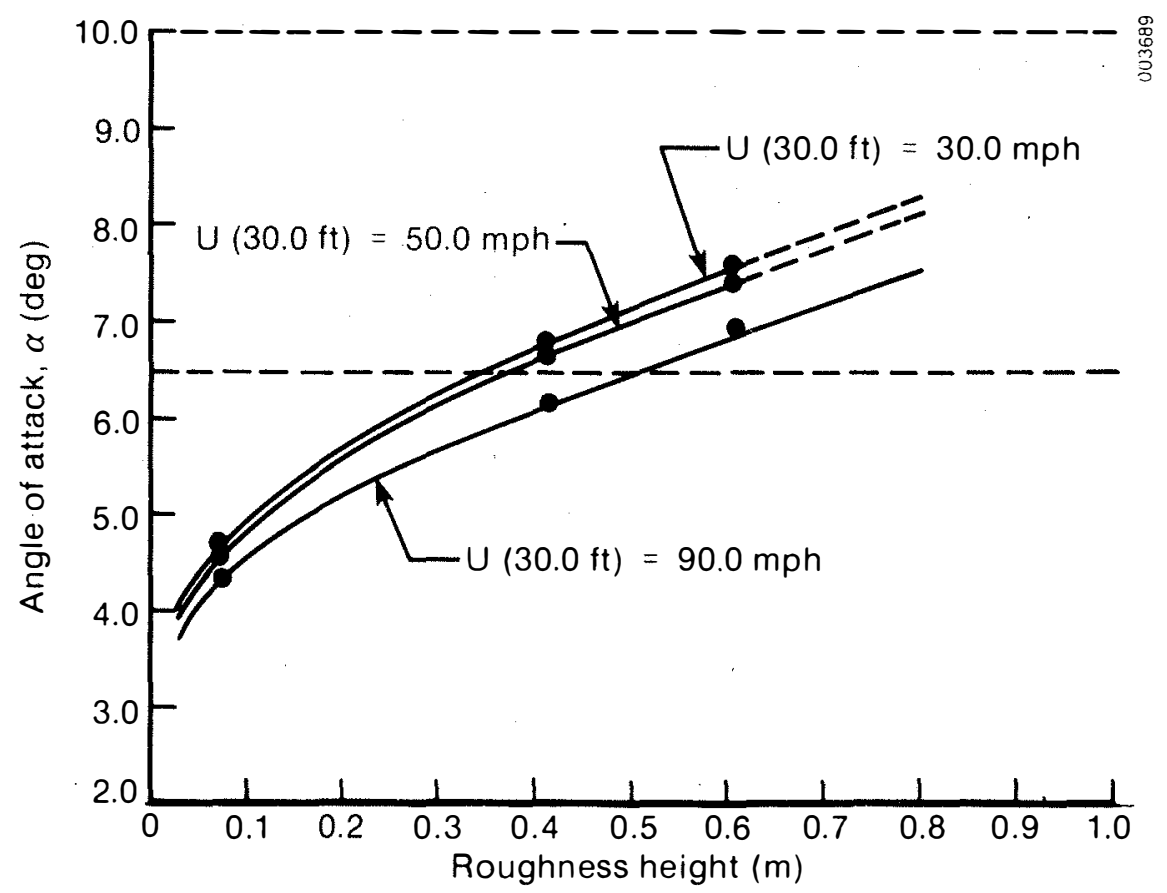

Figure 2-14. Peak Angle of Attack due to Turbulent Lateral Velocity 


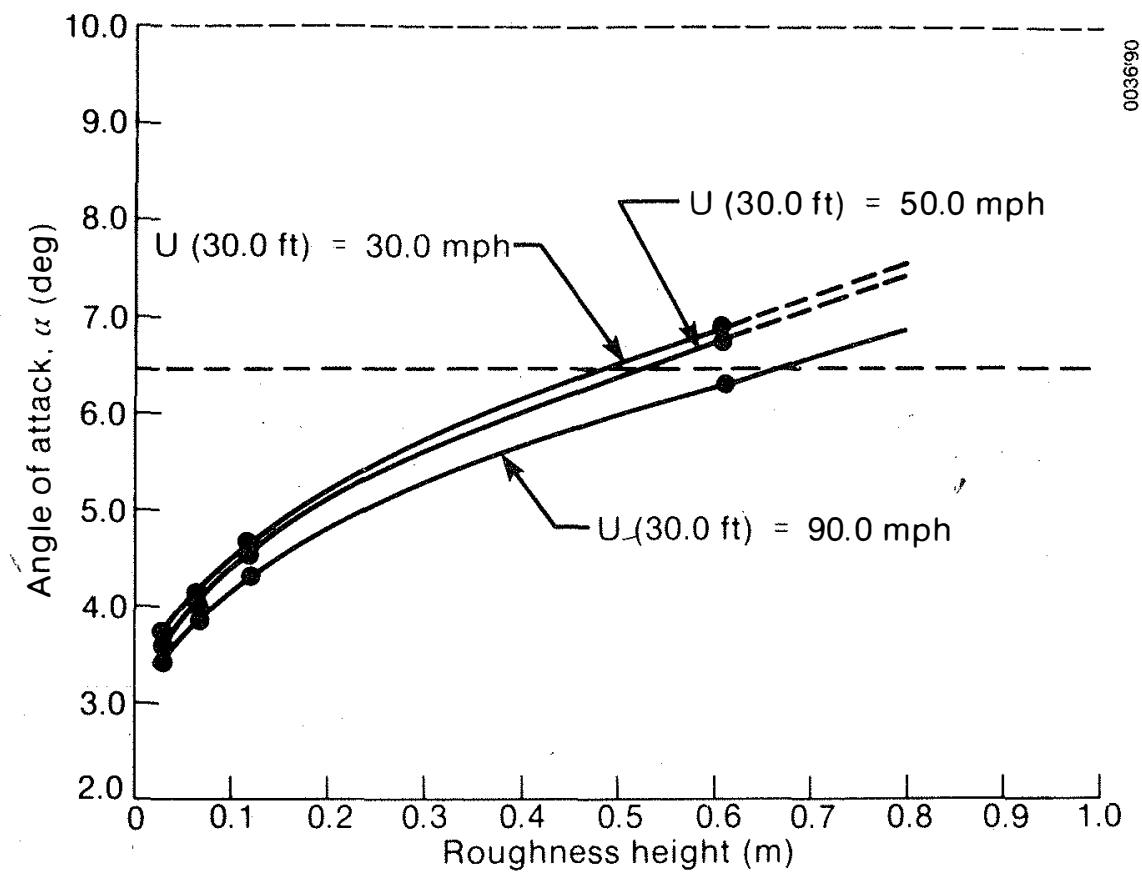

Figure 2-15. Peak Angle of Attack due to Turbulent Vertical Velocity

at $\omega=0.1 \mathrm{~Hz}$ was $8.9^{\circ}$. The surface roughness $z_{0}$ of $3.0 \mathrm{ft}(0.91 \mathrm{~m})$ is rather too large. The surface roughness value is a significant parameter in the determination of the peak angle of attack due to turbulent velocities. The values of the peak angle of attack increase as the surface roughness increases. One interesting feature of the present analysis is that the value of the angle of attack decreases with the increase of the mean wind speed. Figure 2-15 shows that for $0.2 \mathrm{~m}<\mathrm{z}_{\mathrm{o}}<0.4 \mathrm{~m}$ the estimated peak angle of attack due to turbulent vertical velocity for a 90-mph wind and heliostat stored in horizontal position is in the range of $4.8^{\circ}-5.6^{\circ}$. Estimating the peak angle of attack is quite involved. To obtain more reliable values for the angle of attack, recourse should be taken to either full-scale field study or model study in a simulated flow field in the environmental wind tunnel.

Simiu and Scanlan [25, Table 2.2.1] give typical values of surface roughness $z_{0}$ for various types of surfaces and corresponding values of the surface drag coefficients. The table also includes the suggested values of $z_{o}$ for built-up terrains such as outskirts of towns and suburbs, centers of towns, centers of large cities, etc. The suggested value of $z_{0}$ for outskirts of towns and suburbs is in the range of $0.20-0.40 \mathrm{~m}$; for the open fields, $z_{0}$ is in the range of $0.01-0.1 \mathrm{~m}$ depending on the physical characteristics. Figure 2-15 shows that for $0.2 \mathrm{~m}<\mathrm{z}_{\mathrm{o}}<0.4 \mathrm{~m}$, the estimated angle of attack for a 90-mph wind and hellostat stowed in a horizontal position is in the range of

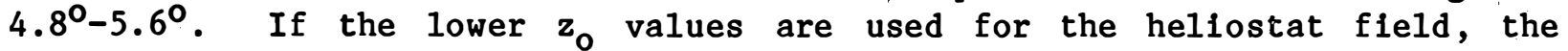
values of the angle of attack are smaller. Figure 2-14 and Figure 2-15 show clearly that the ANSI code values for the angle of attack are too high. 
SECTION 3.0

\section{REDUCTION OF WIND LOADING}

Recent studies $[14,15,16,21,22,32]$ of scale models of solar collectors in environmental wind tunnels show that the present method of determining wind loads on solar collectors, photovoltaic arrays, and hellostats using the guidelines outlined in the ANSI A58.1-1982 bullding code requirements for minimum design loads in buildings and other structures [12] is conservative. Much of the avallable information indicates that the degree of conservatism is significant, but the actual extent of that conservatism must be assessed in more detall. The code was not developed for the low-height structures like solar collectors. The pertinent site-specific meteorological data such as wind velocity distribution in the lower atmosphere, stability features, and turbulent characteristics of the wind field are not reliably known. Since the wind profile changes [25] with the changes of the roughness length $z_{0}$ of the locality of the structure, values depending solely on the alrport data should not be used in optimum design without carefully considering the terrain conditions, local surface roughness, orientation of the heliostats, and direction of the wind.

Ravindra et al. [33] developed an interesting methodology to determine the design wind loads on structures based on the statistical parameters of the lifetime maximum wind speed, the annual maximum wind speed, and the daily maxImum wind speed. Ravindra et al. use the general equation for determining the wind pressure and consider ail the parameters (pressure coefficient, effective velocity pressure, velocity pressure coefficient that depends on the type of exposure and helght above the ground, gust factors that depend on the response characteristics of the structure, and the basic wind speed measured at the reference height) as random varlables. The mean wind pressure and coefficient of variation of the wind pressure are expressed as functions of the mean and. the coefficient of variation of the random variables. Laboratory test results are used to obtain values of coefficients of variation.

Genera1ly, the statistics of wind directions are not considered in the code. Davenport [34] considered two cases of loadings: (1) the direction of maximum wind is uniformly distributed between $+\pi$ and $-\pi$, corresponding to the assumption that the worst response occurs no matter what the wind direction is; and (2) the direction of maximum wind is distributed according to a cosine law. The ratio of the mode in case 2 to the mode value in case 1 , called the direction reduction factor, has been estimated to be 0.72 . Ravindra et a1. [33] considered other factors, such as serviceability and ultimate $11 \mathrm{mit}$ state, and recommend that the mean design wind pressure be reduced by a design resistance factor of 0.75 . Reducing the wind load by $25 \%$ for the variability of wind direction and other considerations should be viewed with caution. Results from simulated laboratory or fleld studies should be used to estimate the reduction of wind loads caused by the varlation in wind direction.

Modification of the shear layer that develops over the hellostat surface is an area of study that may lead to the reduction of drag experienced by the hellostats. Melbourne [35] and Gartshore [36] observed that the sma11-scale 
turbulence increases significantly in the reattaching shear layers on the surEace and consequently increases the magnitude of the high negative surface pressure. It is reasonable to consider that venting the region of separated flow and its subsequent reattachment may be useful in reducing the magnitude of negative pressure. Melbourne [35] observed that venting the separated flow region reduced the negative pressure thereby leading to increased flow stability. It is well known that a pressure reduction (below ambient) on the streamwise surfaces near the leading edge of the flat plate occurs in the region of flow separation. Venting or introducing fluid with a higher level of momentum in the region (the bubble under the reattaching shear layer) is an old technique to delay flow separation and decrease the reduced pressure effect. This can be accomplished by using a slotted eave along the periphery of the surface.

The hellostat modules have sharp edges, and under regular and horizontal stow positions, flow separations near the leading edge and subsequent reattachment occur. A porous eave around the edges of the scale model of a module would be useful for testing in an environmental wind tunnel under simulated flow conditions. Streamlining the windward and leeward edges may be helpful in reducing and even eliminating flow separation and subsequent reattachment.

The air gap between the modules allows high-momentum air to flow through the array and is expected to reduce the windward pressure as well as the negative pressure on the back side. The appropriate amount of air gap for total drag reduction needs to be determined from laboratory tests in the simulated Elows. Investigations of the effects of high porosity in a flat plate on the reduction of total drag may lead to basic knowledge of drag control by allowing high-momentum fluid in the wakes of a flat plate. The test results of Xerikos et a1. [17] did not show significant drag reduction because the slot openings were rather small. A preliminary study of the effects of the solidity ratio of a flat plate placed normal to the flow in the boundary layer by Rangwala and Handy [37] showed that considerable reduction in drag is possible when the solidity ratio is less than $70 \%$.

Experimental results from the wind tunnel study [17] indicated that placing heliostats in the wakes of the heliostats in front helped to reduce wind loads on the heliostats in the wakes. However, wind directions, turbulent intensity, and dynamic response of the structure due to increased turbulence in the wake regions may influence the net outcome. In the simulated flow flelds in the wind tunnel, we need to study the development of wakes behind the heliostats in the inner part of the fleld to gain knowledge of the relative magnitude of the force and moment coefficients that are needed to adequately estimate the wind load on a heliostat.

Perimeter fences [38] are effective in reducing wind loads on the photovoltaic arrays. Fence porosity of $30 \%-50 \%$ and fence height approximately equal to three-quarters of the array height enhance the reduction of wind loads significantly. However, the effect is only limited to the first few rows of arrays along the perimeter. Fences inside the heliostat field, placed at experimentally determined strategic positions, may be helpful to reduce the base-bending moment of the heliostat. 
The experimental works of Randall et a1. [39,40] with parabolic trough solar collectors are of great practical importance. The significant interference effect provided by the upstream collector rows on the lateral and 1ift forces indicates that most collector modules within an array experience force reduction. Randall et a1. have studied the influence of the height of a fence placed three aperture widths upstream of the first row of collectors. The test results indicate that a fence height somewhat less than the full collector height provides the major part of the force reduction. Similar results are also obtained for the influence of the berm height.

Shelter belts made up of trees, shrubs, and other small, structures acting as wind breakers along the perimeter of the hellostat fle'ld may be helpful in reducing the effective wind velocity in the field. Sturrock [41] observed that properly designed shelter belts and wind barriers could be significantly effective in reducing wind load on structures. It is possible to study and evaluate the effectiveness of the barrier in the wind tunnel.

The packing density [42] of heliostats in the fleld had discernible effect on the resulting wind loads. Higher packing density will reduce net wind load on the heliostats. It might be Eeasible to develop an optimum design of the heliostat fleld with relatively higher density in the outer part of the field.

The heliostats at the juter petiphery of the field are subjected to maximum wind load; therefore, they should be designed structurally stronger and more rigid. It is possible to use less rigid and relatively lighter support structure for the heliostats in the interior of the fleld. 


\section{SECTION 4.0}

\section{CONCLUSION AND RECOMENDATIONS}

This study was limited to reviewing and assessing the present design methodology for wind loading on solar collectors, particularly for hellostats, and recommending areas of further investigation to develop realistic criteria for determining adequate wind loads. The results and conclusions of the study can be summarized as follows:

- The present methodology for designing wind load using the outlines given by the ANSI A58.1-1982 Code is conservative.

- The history of the site-specific velocity data is necessary to apply extreme value order statistics for determining design wind speed. Local climatalogical data including wind directions and surface roughness should be used to develop the velocity profile.

- Comparative study of the total force coefficient of a flat plate of various aspect ratios and at various angles of attack shows that the values obtained by using the ANSI Code are always higher.

- The energy spectra obtained by the formulas suggested by varlous authorities were compared with the energy spectra for the code and show that in the flow-frequency domain, the code overestimates spectral values for lower frequencles but underestimates in the region of higher frequencles, including the natural frequencles of hellostats and other solar collectors.

- The angle of attack that results from the fluctuating vertical wind is considerably smaller than the value suggested by the code.

- Development of locally modifled flow over the hellostat has the potential to reduce wind load on the hellostat.

- Appropriate ventilation in the hellostat modules has the potential to reduce dynamic wind load.

Recommendations for further studies that might reduce wind loading on the collector are stated briefly:

- Modifying the flow locally by using a turbulence stimulator in the form of porous eaves around the hellostat will discourage the flow separation at the edges of the heliostats and help to reduce dynamic wind load.

- Investigating the effect of appropriate gaps between the modules will encourage ventilation around the module.

- Studying the effects of the perimeter fences and fences in the fleld around a group of hellostat zones will be useful in overall wind-load reduction.

- Developing a wind rose for the hellostat fleld to estimate the statistics of variation of wind direction. The terrain and topographical aspects of the hellostat field play important local roles in determining the magnitudes of wind speed and direction. The wind direction is not considered 
in the building code. The statistics of the directional variability of the wind are essential in determining wind load rellably. 
SECTION 5.0

\section{REFERENCES}

1. Pugsley, A., "The Safety of Structures," Baltimore, MD: Edward Arnold, 1966.

2. Davenport, A. G., "Estimation of Repeated Loads on Structures with App11cation to Wind Induced Fatigue and Overload," Proceedings of RILEM International Symposium: Effects of Repeated Loading of Materials and Structures, Vo1. 38, 1967.

3. Robertson, L. E., "On Tall Bulldings," Proceedings of a Symposium on Tall Buildings, University of Southhampton, edited by A. Coul1 and B. Stafford-Smith, Oxford, U.K.: Pergamon Press, 1967.

4. Davenport, A. G., "The Dependence of Wind Loads on Meteorological Parameters," Proceedings of International Research Seminar on Wind Effects on Bulldings and Structures, Ottawa: National Research Counc11 of Canada, 1967.

5. Davenport, A. G., "The Nature of Disturbing Forces," Proceedings of RILEM International Symposium: Effects of Repeated Loading of Materials and Structures, Mexico, 1966.

6. Vellozz1, J., and E. Cohen, "Gust Response Factors," Journal of the Structural Division, American Soclety of Civil Engineers, Vol. 94, ST 6, June 1968 .

7. Davenport, A. G., "A Rationale for Determination of Design Wind Velocities," J. Structural Division, American Society of Civil Engineers, Vo1. 86, No. ST 5, Proc. Paper 2476, May 1960.

8. Gumbe1, E. J., "Statistical Theory of Extreme Values and Some Practical Applications," Applied Mathematics Series No. 33, Washington, DC: National Bureau of Standards, 1954.

9. Thom, H. C. S., "Frequency of Maximum Wind Speeds," Proc. Separate No. 539, American Society of Clv11 Englneers, Vo1. 80, November 1954.

10. Lleblein, J., "Method of Analyzing Extreme Value Data," Technical Note 3053, Washington, DC: National Advisory Committee for Aeronautics, 1954.

11. Thom, H. C. S., "New Distribution of Extreme Winds in the United States," J. American Soclety of Clvil Engineers, Vol. 94, No. ST 7, July 1968.

12. American National Standard A58.1-Building Code Requirements for Minimum Design Loads in Bulldings and Other Structures, NY: American National Standard Institute, 1982.

13. Simiu, E., "Wind Climate and Fallure Risks," J. Structural Division, American Society of Civil Engineers, Vol. 102, ST 9, September 1976. 
14. Murphy, L. M., An Assessment of Existing Studies of Wind Loading on Solar Collectors, SERI/TR-632-812, Golden, CO: Solar Energy Research Institute, February 1981.

15. Roschke, E. J., Wind Loading on Solar Concentrators: Some General Considerations, DOE/JPL-1060-66, JPL Publication 83-101, Pasadena, CA: Jet Propulsion Laboratory, May 1984.

16. Peglow, S. G., Wind Tunnel Test of a Full Scale Hellostat, SAND 79-8034, Livermore, CA: Sandia Laboratorles, June 1979.

17. Xerikos, J. et al., "The Aerodynamics of Hellostats for Solar Power Plant Applications," Proceedings of the 5th International Conference on Wind Engineers, 1979, 2 vols., edited by J. E. Cermak, Oxford, U.K.: Pergamon Press, 1980.

18. McDonald, J. R., Wind Effects on Solar Tower Generator, Lubbock, TX: Institute for Disaster Research, Texas Tech University, 1978.

19. Cermak, J. E., "Applications of Fluid Mechanics to Wind Engineering--A Freeman Scholar Lecture," J. Fluid Engineering, Vol. 97, March 1975.

20. Bhaduri, S., "Simulation of Urban Atmosphere for Diffusion Study," Engineer, Vo1. VI, No. 2, 1973.

21. Lindsay, J. E., Force and Pressure Tests of Solar Collector Models in the Vought Corporation Systems Division Low Speed Wind Tunne1, SAND 76-7007, Albuquerque, NM: Sandia Laboratories, May 1979.

22. Randa11, D. E., D. D. McBride, and R. E. Tate, Parabollc Trough Solar Collector Wind Loading, SAND 79-8034, Albuquerque, NM: Sandia Laboratories, June 1979.

23. Task Committee on Wind Forces, "Wind Forces on Structures," Transactions, American Society of Civil Engineers, Vol. 126, No. 3269, 1961.

24. Simiu, E., "Wind Spectra and Dynamic along Wind Response," J. Structural Division, American Soclety of Civil Engineers, Vol. 100, No. ST9, September 1974.

25. Simiu, E., and R. H. Scanlan, Wind Effects on Structures, NY: John Wiley and Sons, 1978.

26. Kaima1, J. C., et al., "Spectra1 Characteristics of Surface-Layer Turbulence," J. Royal Meteorological Soclety, Vol. 87, 1961.

27. Lumley, J. L., and H. A. Panofsky, The Structure of Atmospheric Turbulence, NY: John Wiley \& Sons, 1964.

28. Davenport, A. G., "The Spectrum of Horizontal Gustiness Near the Ground in High Winds," J. Royal Meteorological Soclety, Vol. 87, 1961. 
29. Daniels, G. E., ed., Terrestrial Environment (Climatic) Criteria Guidelines for Use in Aerospace Vehicle Development, 1973 Revision, NASA TM X-64757, Huntsville, AL: Marshall Space Flight Center, 1973.

30. McDonne11 Douglas Astronautics Company, Optimization of the Second Generation Heliostat and Specification, SAND 82-8181, May 1982 .

31. Vann, W. P., "Wind Effects on Solar Tower Generators," Final Report, Subcontract No. 77-TT-1 (Sub-Task b.), Lubbock, TX: Energy Foundation of Texas, Texas Tech University, 1978.

32. Bechtel National, Inc., Wind Designs on Flat Panel "Photovoltalc Array Structures, SAND 79-7057, Livermore, CA: Sandia Laboratorles, 1980.

33. Ravindra, M. K., et al., "Wind and Snow Load Factors for Use in Load and Resistance Factor Design," J. Structural Division, American Society of Clvil Engineers, Vol. 104, ST 9, 1978.

34. Davenport, A. G., "The Prediction of Risk under Wind Loading," Proc. of the Second International Conference on Structural Safety and Reliability, Technical University In Munich, Munich, West Germany, Dusse1dorf, West Germany: Werner-Verlag, September 1977.

35. Melbourne, W. H., "Turbulence Effects on Maximum Surface Pressures--A Mechanism and Possibility of Load Reduction," Proceedings of the Fifth International Conference on Wind Engineering, Ft. Colilns, CO: Colorado State University, July 1979.

36. Gartshore, I. S., "The Effects of Free-Stream Turbulence on Drag of Rectangular Two-Dimensional Prisms," Boundary Layer Wind Tunne1, Report 4-73, Canada: University of Western Ontario, 1973.

37. Rangwala, S., and E. Handy, Drag of a Flat Plate of Variable Solidity Ratio Placed Normal to Flow in a Boundary Layer, Project Report for ME 3506, Advanced Fluld Mechanics I, E1 Paso, TX: Mechanical and Industrial Engineering Department, December 1983.

38. Martin Marietta Corp., Hellostat Field Wind Effects Tests, SAN/20422-2, San Francisco, CA: Department of Energy, February 1979.

39. Randa11, D. E., D. D. McBride, and R. E. Tate, Steady-State Wind Loading on Parabolic Trough Solar Collectors, SAND 79-2134, Albuquerque, NM: Sandia National Laboratories, August 1980.

40. Randa11, D. E., R. E. Tate, and D. A. Powers, Experimental Results of Pitching Moment Tests on Parabolic-Trough Solar-Collector Array Configurations, SAND 82-1569, Albuquerque, NM: Sandia National Laboratories, December 1982.

41. Sturrock, J. W., "Aerodynamic Studies of Shelterbelts in New Zealand," New Zealand Journal of Sclence, Vol. 12, No. 4, 1969. 
42. Peterka, J. A., B. Blenkiewicz, and J. E. Cermak, Technical Feasibility of Innovative Concepts for Avolding or Reducing Wind Loads on Concentrator Collectors - Task I Report for Solar Energy Research Institute, Fort Collins, CO: Colorado State University, March 1984. 


\section{DISTRIBUTION LIST}

Kosta Achin

Sandia National Laboratories

Division 8473

P.0. Box 969

Livermore, CA 94550

R. E. Akins, Ph.D.

Professor, Engineering Sclence and Mechanics

Virginia Polytechnic Institute and State University

Blacksburg, VA 24061

Don Bartlett

Boeing Engineering and Construction Company

Ma11 Stop 9A-42

P.0. Box 3707

Seattle, WA 98125

David Blake, Ph.D.

Engineering Manager

Acurex Corporation

485 Clyde Avenue

Mountain View, CA 94042

Floyd Blake

ARCO Ventures Company

7061 South University B1vd.

Littleton, CO 80122

John Cermak, Ph.D.

Professor, Civil Engineering

Dept. of Civil Engineering

Fluid Mech. and Wind Eng. Program

Colorado State University

Fort Collins, CO 80523

B111 Delemeter, Ph.D.

Sandia National Laboratories

Division 8453

P.0. Box 969

Livermore, CA 94550

William Dickhart

Assistant to the Director

The Budd Company

Fort Washington, PA 19034
Robert Gervals

McDonnel Douglas Company

5301 Bolsa Avenue

Huntington Beach, CA 92647

H. Gerwin, Ph.D.

Gerwin Research

14305 Anstead Road

Silver Spring, MD' 20904

Roger Gillette

Boelng Engineering and Construction Company

P.0. Box 3707

Seattle, WA 98125

Jim Leonard, Ph.D.

Sandia National Laboratories

Division 6227

P.0. Box 5800

Albuquerque, NM 87115

John Lucas, Ph.D.

Jet Propulsion Laboratory

4800 Oak Grove Drive

Pasadena, CA 94103

Monte McGlaum

LaJet Company

3131 Ant111y Road

Abllene, TX 79605

Clayton Mavis

Sandia National Laboratories

Division 8473

P.0. Box 969

Livermore, CA 94550

Jon Peterka, Ph.D.

Professor, Civil Engineering

Dept. of Civil Engineering

Fluid Mech. and Wind Eng. Program

Colorado State University

Fort Collins, CO 80523

J. T. Pearson, Ph.D.

Purdue University

Mechanical Engineering Building

West Lafayette, IN 47907 
Tim Reinhold, Ph.D.

Center for Building Technology

National Bureau of Standards

Washington, DC 202034

Bob Reuter, Ph.D.

Sandia National Laboratories

Division 1523

P.0. Box 5800

Albuquerque, NM 87115

Jim Rogan, Ph.D.

McDonnel Douglas Company

5301 Bolsa Avenue

Huntington Beach, CA 92647

T. W. Rogers

United Space Boosters

2-EO

P.O. Box 1626

Huntsville, AL 35807

E. J. Roshke, Ph.D.

The Jet Propulsion Laboratory

California Institute of Technology 4800 Oak Grove Drive

Pasadena, CA 91109

Aharon Roy

Head, Solar Power Laboratory

Department of Chemical Engineering

Ben-Gurion University of Negev

P.0. Box 653

Beer-Sheva 84105, ISRAEL

Dan Sa11is

Dan-Ka Products

790 Umat111a

Sulte 212

Denver, CO 80204

John Schaeffer, Ph.D.

Manager of Projects

Projects Department

Acurex Corporation

485 Clyde Avenue

Mountain View, CA 94042
Martin Scheve

Department of Energy

CE-314, Room 5H-041

Forrestal Bullding

1000 Independence Avenue, S.W.

Washington, DC 20585

Jeff Shingleton

49 E1m Avenue

Takoma Park, MD 20912

Jack Swearingen, Ph.D.

Sandia National Laboratories

Division 8453

P.0. Box 969

Livermore, CA 94550

H. Tielman, Ph.D.

Professor, Engineering Sclence and Mechanics

Virginia Polytechnic Institute and State University

Blacksburg, VA 24061

A. Thomas

Instrumentation and Services Unit

Indian Institute of Science

Bangalore - 560-012

INDIA

Kene11 J. Touryan, Ph.D.

Vice President, R\&D

Mt. Moriah Trust

6200 Plateau Drive

Englewood, CO 80111

Lee Weinstein

McDonne1 Douglas Company

5301 Bolsa Avenue

Huntington Beach, CA 92647

Frank Wilkins

Department of Energy

CE-314, Room 5H-041

Forrestal Building

1000 Independence Avenue, S.W.

Washington, DC 20585 


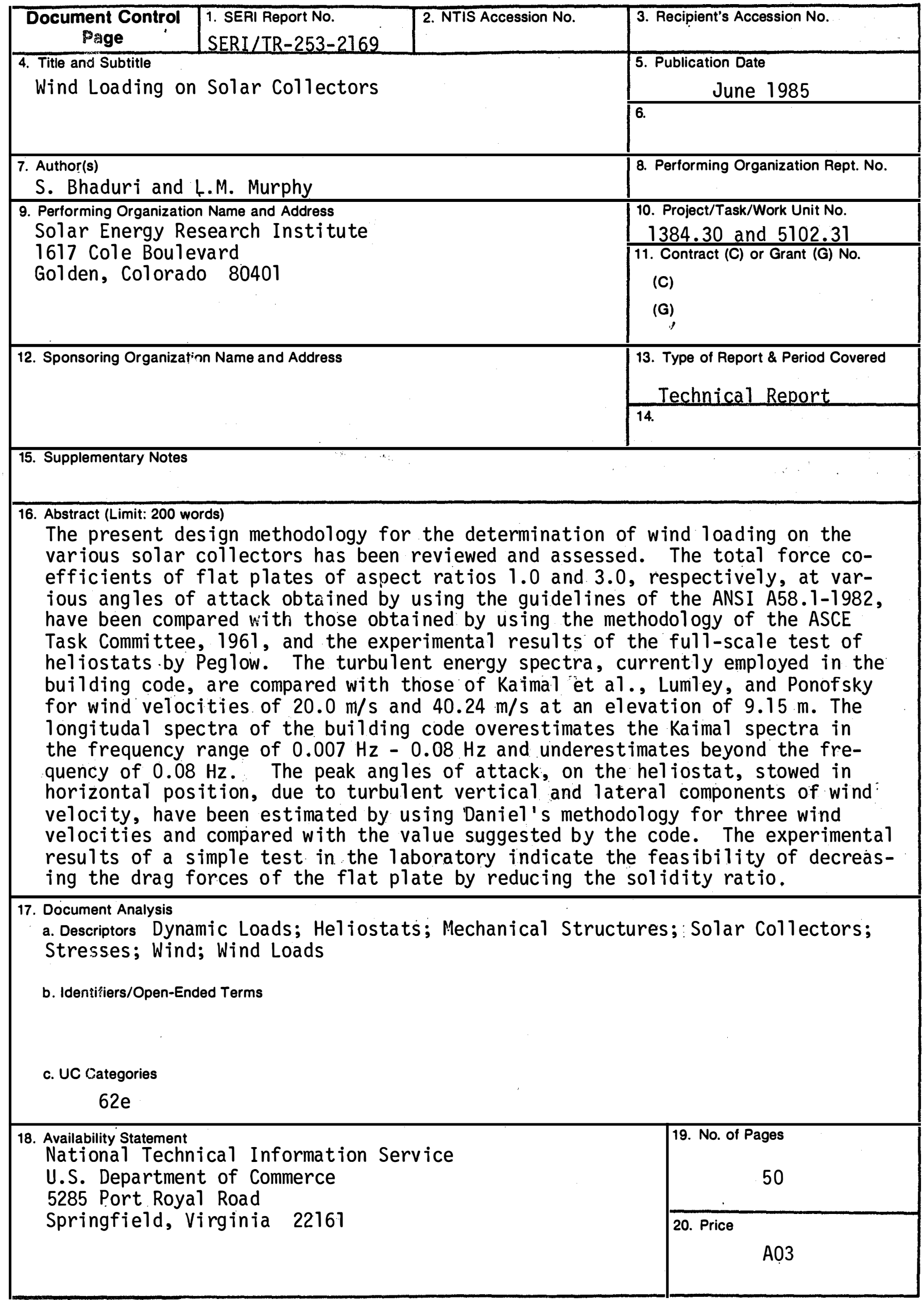

